Article

\title{
Environmentally Sustainable Biogas? The Key Role of Manure Co-Digestion with Energy Crops
}

\author{
Alessandro Agostini ${ }^{1,2, *}$, Ferdinando Battini ${ }^{3}$, Jacopo Giuntoli ${ }^{1}$, Vincenzo Tabaglio ${ }^{3}$, \\ Monica Padella ${ }^{1}$, David Baxter ${ }^{1}$, Luisa Marelli ${ }^{1}$ and Stefano Amaducci ${ }^{3}$
}

1 European Commission, Joint Research Centre (JRC), Institute for Energy and Transport (IET), Sustainable Transport Unit, Westerduinweg 3, 1755LE Petten, The Netherlands;

E-Mails: jacopo.giuntoli@ec.europa.eu (J.G.); monica.padella@jrc.ec.europa.eu (M.P.); david.baxter@ec.europa.eu (D.B.); luisa.marelli@jrc.ec.europa.eu (L.M.)

2 ENEA-Italian National Agency for New Technologies, Energy and the Environment, Via Anguillarese 301, 00061 Rome, Italy

3 Institute of Agronomy, Genetics and Field crops, Università Cattolica del Sacro Cuore, 29122 Piacenza, Italy; E-Mails: battifer@libero.it (F.B.); vincenzo.tabaglio@unicatt.it (V.T.); stefano.amaducci@unicatt.it (S.A.)

* Author to whom correspondence should be addressed; E-Mail: alessandro.agostini@ec.europa.eu; Tel.: +31-224-565-258.

Academic Editor: Thomas E. Amidon

Received: 25 March 2015 / Accepted: 27 May 2015 / Published: 3 June 2015

\begin{abstract}
We analysed the environmental impacts of three biogas systems based on dairy manure, sorghum and maize. The geographical scope of the analysis is the Po valley, in Italy. The anaerobic digestion of manure guarantees high GHG (Green House Gases) savings thanks to the avoided emissions from the traditional storage and management of raw manure as organic fertiliser. GHG emissions for maize and sorghum-based systems, on the other hand, are similar to those of the Italian electricity mix. In crop-based systems, the plants with open-tank storage of digestate emit 50\% more GHG than those with gas-tight tanks. In all the environmental impact categories analysed (acidification, particulate matter emissions, and eutrophication), energy crops based systems have much higher impacts than the Italian electricity mix. Maize-based systems cause higher impacts than sorghum, due to more intensive cultivation. Manure-based pathways have always lower impacts than the energy crops based pathways, however, all biogas systems cause much higher impacts than the current Italian electricity mix. We conclude that manure digestion
\end{abstract}


is the most efficient way to reduce GHG emissions; although there are trade-offs with other local environmental impacts. Biogas production from crops; although not providing environmental benefits per se; may be regarded as an option to facilitate the deployment of manure digestion.

Keywords: maize; manure; sorghum; biogas; GHG emissions; environmental impacts

\section{Introduction}

According to the International Panel on Climate Change (IPCC), human interference with the climate system is occurring, and climate change poses risks for human and natural systems [1]. In order to contribute to the global efforts to reduce Green House Gases (GHG) emissions and limit global warming, the European Union set an ambitious GHG reduction target, $-20 \%$ compared to 1990 levels, to be achieved by the year 2020. European member states are committed both to increase their share of renewable energy sources and to reduce their GHG emissions. Currently, no mandatory sustainability criteria have been formulated at a European level for solid biomass and biogas used for power and heat production. However, the European Commission (EC) provided recommendations to Member States to develop criteria similar to the ones designed for transport biofuels [2]. A recent document from the EC presented the state of play of bioenergy in the EU [3] and introduced updated typical and default GHG emissions values for a large selection of bioenergy pathways, including several pathways for the production of power by anaerobic digestion of manure, maize and biowastes [4]. This document suggests the application of a GHG emission savings threshold of at least $70 \%$ for all biogas pathways compared to the fossil fuel comparator defined. According to the JRC data which accompanied the EC document [4], only manure-based plants would achieve such a threshold. However, with the suggested suspension of the mass balance approach for biogas plants and, therefore, the possibility to 'average' the GHG emissions among co-digested substrates, the use of about $30 \%$ (wet mass) of maize substrate in co-digestion plants with a gas-tight storage of digestate would still allow to comply with the criteria [4].

In Italy the incentives for electricity production from Anaerobic Digestion (AD) have fuelled, in the last 5 years, rapid growth of investments in biogas plants and biogas production technologies and a significant diversion of maize crops to bioenergy [5]. Starting in 2013, the Italian law [6] has modified the tariffs and subsidies for renewable electricity fed into the grid; the feed-in tariffs depend now on the biogas plant capacity, on the specific substrate used and on the technologies employed to reduce the environmental impacts.

These incentives, although lower than those provided in the previous years, still make biogas production profitable, and the number of new biogas plants built is steadily increasing [7]. At the end of 2012, there were 994 biogas plants in Italy with a total installed capacity of $756 \mathrm{MW}_{\text {el. }}$ Of these, $17.7 \%$ use only livestock manure as substrate, $20.1 \%$ only energy crops and $62.2 \%$ both types of biomass and other agro-industrial waste streams. However, when these shares are calculated on the basis of installed capacity, the picture is very different; $74.2 \%$ of the installed capacity is based on co-digestion, $22.4 \%$ on energy crops only, while just $3.2 \%$ on manures only. 
Biogas can be combusted on-site to produce heat and power or it can be upgraded to biomethane to be either injected into the natural gas grid or compressed and used as transportation fuel. Biogas can be produced from nearly all kind of biological materials deriving from the primary agricultural sectors and from various industrial and domestic organic waste streams.

Biogas production and use are normally perceived as a clean and sustainable option of energy generation that can guarantee significant GHG savings if compared to fossil fuels. However, the environmental impacts associated with $\mathrm{AD}$ are strongly dependent on many factors, mainly: the choice of substrate, the technology adopted and the operational practices.

When energy crops are used as substrates for biogas production, fossil fuels and chemicals are used for the cultivation and transport of such substrates and various emissions of pollutants arise from the plant's operation, biogas utilisation and residues management [8-10].

On-farm biogas production from manure has shown high potential to mitigate some of the environmental impacts associated with intensive dairy farming, especially as a consequence of the avoided emissions from manure management. Battini et al. [11] concluded that on-farm manure anaerobic digestion is an effective practice to significantly reduce GHG emissions and non-renewable energy consumption; however, local impacts (i.e., photochemical ozone formation) may actually worsen.

Boulamanti et al. [12] analysed the environmental sustainability of several biogas systems running on maize, manure and their co-digestion. They found that GHG emissions of biogas electricity are strongly influenced by the actual plant design, with GHG savings (referred to the emissions of the European electricity mix) ranging from more than $100 \%$ for manure-based systems (thanks to the credits for the avoided methane emissions from raw manure storage) to 3\% for maize-only-based systems with open storage of the digestate. They found also that trade-offs among the different environmental impacts exist and an analysis of impact categories other than global warming is needed to fully grasp the environmental benefits or impacts of biogas production. The relevance of biogas production on impact categories related to atmospheric pollution (PM (Particulate Matter) emissions, photochemical ozone, acidification and eutrophication) is widely reported in literature [13-18].

Maize plays an important role as a dedicated energy crop because of its high biomass productivity and methane potential, an established cultivation technique and the large availability of suitable genetic materials. However, maize cultivation, as well as all agricultural systems, has implications for water use and supply [19] with the potential to increase existing pressures on water resources, in terms of both quality and quantity [20]. Given the expected increase of freshwater related risks (water scarcity, draught, reduced water quality) due to climate change [21], other crops may be a more suitable option in areas where irrigation water availability will not be sufficient for crops with higher water needs, such as maize. Many studies have indicated that sorghum is an interesting energy crop that could potentially constitute a valuable alternative to maize in low fertilisers and water input conditions [22-26]. The ability of sorghum to take up soil nitrogen [27] and to grow in arid conditions [26] makes it an ideal choice in areas where nitrogen leaching should be reduced.

In addition to the direct impacts arising from the cultivation and processing of crops, the use of agricultural products for bioenergy production can cause indirect effects (market mediated) in terms of changes of land use (e.g., converting forest land and grassland to cropland) with the associated carbon emissions of such land-use change, hereafter called Indirect Land-Use Change (ILUC) carbon 
emissions [28-30]. These indirect effects have the potential to increase the GHG emission associated with certain bioenergy feedstocks.

A thorough analysis using a comprehensive and transparent LCA approach is needed to make an accurate assessment, not only of GHG emissions, but also of other environmental impacts that may arise from biogas production. The overall goal of this study is to analyse and quantify at farm level the environmental impacts (and the trade-off among environmental impact categories) associated with the production of electricity via anaerobic digestion of manure, maize and sorghum silage. A further aim is to identify which practices lead to a reduction of the environmental impacts of electricity production via anaerobic digestion.

\section{Materials and Methods}

This work follows a Life Cycle Assessment (LCA) methodology to assess the environmental impacts of electricity production via anaerobic digestion. LCA is a structured and internationally standardised method aimed at quantifying all relevant emissions and resources consumed and the related environmental and health impacts and resource depletion issues that are associated with the entire life cycle of any goods or services ("products") [31]. In this study, the LCA was performed according to ISO 14040 and 14044 standards requirements [32,33], using the software GaBi 6.3 from PE International [34].

\subsection{Goal and Scope Definition}

We developed a comparative attributional LCA aimed at assessing three different agricultural substrates used for biogas production via anaerobic digestion. The systems analysed consist of three different uses of 75 ha of agricultural land in the Po Valley. In the first system the substrate is manure produced by dairy cattle, as reported in a previous work [11]. In the second system the production of biogas is solely from maize silage. The third system consists in the anaerobic digestion of sorghum silage (see Figure 1).

Currently, many biogas plants tend to collect the anaerobic digestion residue (called hereafter "digestate") in open lagoons or tanks. When the digestate is stored in open containers, ammonia, methane and nitrous oxides are emitted as the digestion process continues. Other biogas plants minimise these residual emissions by fitting the digestate storage tanks with gas-tight membranes or by using flexible storage bags. Therefore, for each of the systems analysed, two different ways of storing the digestate are considered: open storage, and covered (gas-tight) storage tanks with recovery of the off-gas. The systems compared are therefore six:

$10=$ anaerobic digestion of manure with digestate open storage (Manure open)

$1 \mathrm{c}=$ anaerobic digestion of manure with digestate closed storage (Manure closed)

$2 \mathrm{o}=$ anaerobic digestion of maize with digestate open storage (Maize open)

$2 \mathrm{c}=$ anaerobic digestion of maize with digestate closed storage (Maize closed)

$3 \mathrm{o}=$ anaerobic digestion of sorghum with digestate open storage (Sorghum open)

$3 \mathrm{c}=$ anaerobic digestion of sorghum with digestate closed storage (Sorghum closed) 

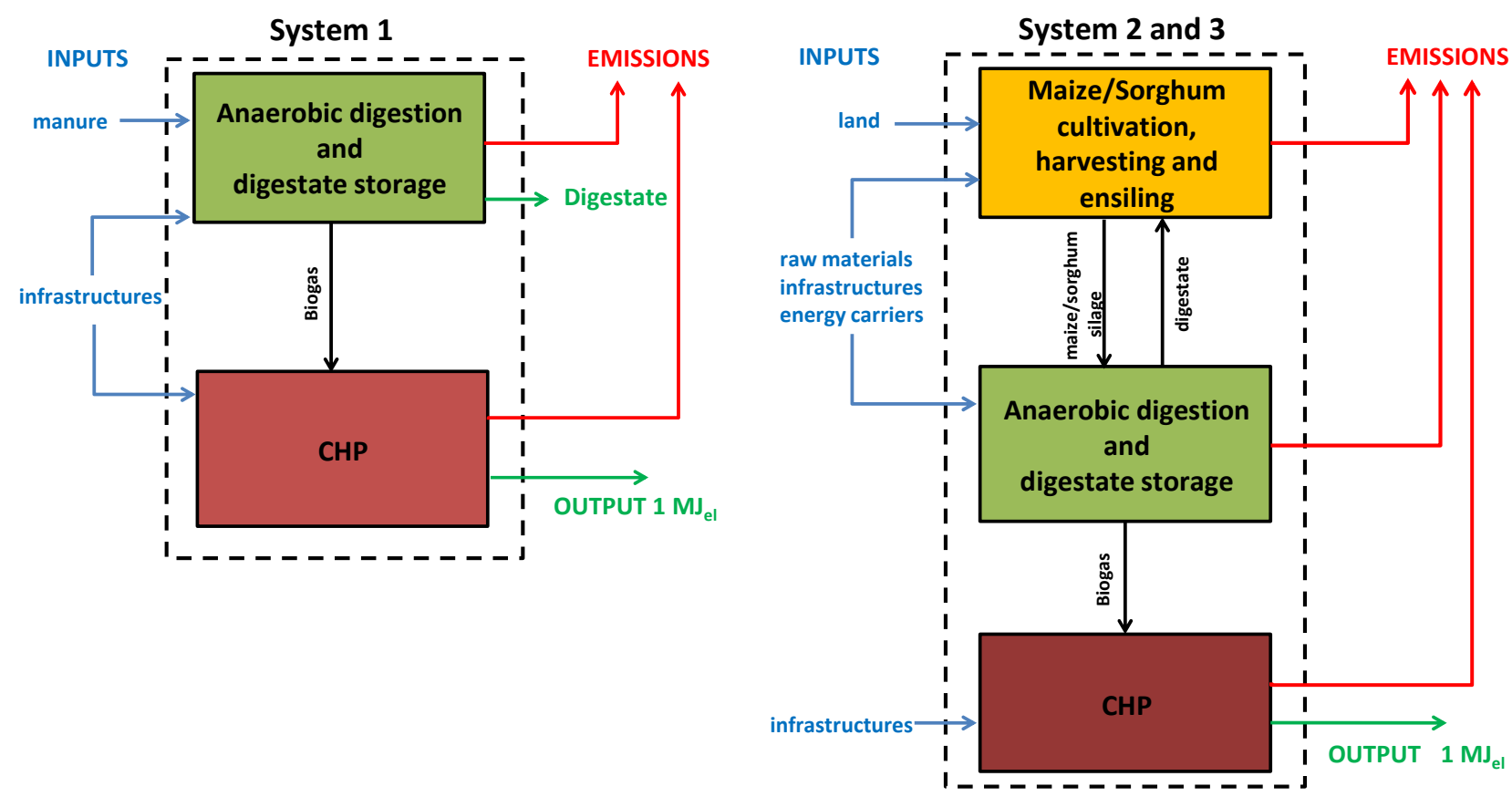

Figure 1. System boundaries considered in the study for biogas production from manure (System 1) and from energy crops (Systems 2 and 3).

In order to facilitate the interpretation of the results of this study, the impacts associated with the production of electricity from the Italian electricity mix are reported for comparison. However, the results presented, obtained with an attributional approach, can (and should) be used only for micro-scale decision support or emissions accounting since this approach is purely descriptive and not change-oriented. For decision support at large scale, a consequential approach should be used and market-mediated impacts should be included in the analysis $[31,35]$.

One of the most relevant market-mediated impacts associated with food/feed crops used for bioenergy purposes are the additional GHG emissions due to the displacement of food or feed for energy and the associated ILUC effect. These additional emissions were integrated in the analysis and detailed into the supplementing material of the current analysis in order to provide stakeholders and policy makers what the relative contribution of ILUC would be in the case of maize.

A sensitivity analysis on the energy crops, to assess the effect of employing alternative agricultural practices, is reported in the Appendix; in particular Conventional Tillage (CT) and No-Tillage (NT) management schemes were compared as alternative soil management strategies.

Additional sensitivity analyses were carried out to understand the impact of the most uncertain input values (namely methane leakages, field emissions and storage emissions) and reported in the Appendix.

The impacts assessed were: GHG emissions, acidification, freshwater and marine eutrophication, particulate matter emission and photochemical ozone formation. The assessment is performed at midpoint using the methods recommended by the ILCD Handbook [36]. In addition, the technical quantities 'primary energy from non-renewable resources', land use and water consumption were included in the analysis.

The final goal of the study is to provide stakeholders, policymakers and academics a complete picture of the environmental impacts associated with biogas produced from three possible substrates 
for biogas production in Italy and develop recommendations on the viable practices that can reduce the environmental burden of electricity production via anaerobic digestion.

\subsection{Functional Unit and System Boundaries}

The functional unit is $1 \mathrm{MJ}$ of electricity produced at the farm gate. Ideally, in order to calculate GHG savings, the bioenergy system should be evaluated against the energy system it displaces. In practice, it is extremely complex and subject to very large uncertainties to identify which energy source would be replaced and by what amount [35,37]. As a consequence, in this work, the environmental impacts of the bioenergy systems analysed are presented and compared to those of the average Italian electricity mix (from PE International [34]).

For the systems running on manure, the reference system also includes the alternative use of manure. If manure is not anaerobically digested, the common agricultural practice consists in its storage in an open tank, causing high pollutant emissions, and then its use as organic fertiliser. The management of slurries and manures is one of the main sources of pollutants and GHG emissions from the livestock sector $[11,38]$. The emissions associated to the management of raw manure are assigned as a credit to the manure-based biogas pathways and are called hereafter 'manure emission credits'.

No credits for mineral fertiliser replacement are given to the digestate because the fertilizing properties of digestate and raw manure are considered equivalent in the long term [39-41]. Fertiliser credits are not given to energy crops systems as the digestate produced is recycled in the same fields where the crops are grown, and the reduced need for mineral fertiliser is already accounted for.

\subsection{Life Cycle Inventory (LCI)}

LCI involves a systematic inventory of the input and output energy and material flows during the entire life-cycle. The software used for the analysis is Gabi 6.3 [34]. The data that constitute the inventory used in this work derive mostly from peer reviewed literature or from primary data from field-studies. The data used for the background processes were obtained (if not otherwise specified) from the commercial database Ecoinvent [34,42]. No major gaps were identified in the background data collection; however, the uncertainty due to geographical, technological and temporal representativeness of the background data may be significant. The inventory is aggregated for the two main phases of the whole biogas to electricity chain: substrate supply and energy production.

\subsubsection{Substrate Supply}

The systems 10 and 1c are derived from Battini et al. [11], where the environmental impacts of $1 \mathrm{~kg}$ of milk produced with and without a biogas plant for on-farm manure digestion were assessed. These systems involved on-farm production of biogas solely from the manure produced by the farm's 185 dairy cows and their replacements. The annual production of liquid manure consisted of $6950 \mathrm{~m}^{3}$. To obtain the data relative to the functional unit of $1 \mathrm{MJ}$ of electricity produced, the difference between the two systems (dairy farm with and without biogas plant) is calculated for both the open and closed storage systems and divided by the total amount of electricity produced. All the input data and assumptions can be found in [11] and will not be repeated here in detail. 
Systems 2 and 3 include inputs and emissions for the cultivation of energy crops. Information and input data used to model the cultivation phase can be found in the Appendix, together with the data used for field emissions from fertilizers application and diesel combustion (Tables A1-A4). Also the methodology used for the calculation of the ILUC carbon emissions is reported in Appendix.

\subsubsection{Energy Production}

Details on the biogas plant for systems 10 and 1c are reported in [11]. For systems 2 and 3 the biogas plant consists of two anaerobic digesters (continuous stirred-tank reactors), operating at 38-40 ${ }^{\circ} \mathrm{C}$ and of two storage tanks. The biogas produced is firstly desulfurized and dehumidified and then converted to electrical and thermal energy by means of a Combined Heat and Power (CHP) internal combustion engine. The electricity produced is fed into the national electricity grid. Thermal energy, in the cases analysed here, is used solely to supply the necessary heat to the digesters; the rest of the thermal energy is not used. This is the common practice for farm-based biogas plants.

The biogas plant and CHP data in Table 1 are taken mainly from [43-45]. The dry matter losses during ensiling were considered to be equal to $10 \%$ [46]. The yield of methane obtained from maize silage was assumed to be $0.331 \mathrm{~m}^{3} \cdot \mathrm{kg}^{-1} \mathrm{VS}$, as monitored by Fabbri et al. [45]; while, for sorghum, it was assumed that the yield would be $15 \%$ lower $[47,48]$.

Table 1. Summary of the main technical characteristics of the biogas plant considered.

\begin{tabular}{ccccc}
\hline Parameter & Unit & Manure & Maize & Sorghum \\
\hline Methane production & $\mathrm{m}^{3} \cdot \mathrm{kg}^{-1} \mathrm{VS}$ & 0.220 & 0.331 & 0.281 \\
Methane energy content LHV & $\mathrm{MJ} / \mathrm{Nm}^{3}$ & 36 & 36 & 36 \\
(Lower Heating Value) & & & & \\
Retention time & days & $30-35$ & $140-145$ & $140-145$ \\
Digester lifetime & years & 20 & 20 & 20 \\
CHP lifetime & years & 10 & 10 & 10 \\
Gross Electrical efficiency & $\%$ & 32 & 38 & 38 \\
Internal power consumption (plant) & $\%$ of produced & 11.9 & 8.4 & 8.4 \\
Internal power consumption (engine) & $\%$ of produced & 3 & 3 & 3 \\
Electricity produced (open/closed) & MWh $\cdot \mathrm{yr}^{-1}$ & $329.8 / 368.8$ & $1189.8 / 1273.4$ & $1135.2 / 1223.0$ \\
\hline
\end{tabular}

The gross electrical efficiency is assumed to be equal to $32 \%$ for the smaller biogas engine running on manure [11] and equal to $38 \%$ for the medium sized biogas engine running on energy crops [49,50].

The operating time was considered to be $8000 \mathrm{~h}$ per year. The energy production inputs were infrastructures and lubricating oil; the datasets for these inputs were taken from Ecoinvent [42].

The higher production in the systems with closed storage for the digestate is due to the recovery of the additional biogas produced during digestate storage.

The methane slip from the biogas engine is estimated according to Kristensen et al. [51] for gas fired CHP units with power less than $25 \mathrm{MW}$ (Table 2). This value is in agreement with the data reported by Liebetrau et al. [52] for biogas engines. To account for the accidental emissions due to membrane cover permeability [53], leaky gaskets, maintenance operations and flaring or venting of biogas overproduction [52], a leak of $1 \%$ of the methane produced in the biogas plant is assumed to happen in all the systems. 
Table 2. Emissions from the CHP engine considered in the biogas plant, per GJ biogas combusted (adapted from [51]).

\begin{tabular}{ccc}
\hline Emissions & Unit & Quantity \\
\hline $\mathrm{NO}_{\mathrm{x}}$ & $\mathrm{g} \cdot \mathrm{GJ}^{-1}$ & 540 \\
Methane & $\mathrm{g} \cdot \mathrm{GJ}^{-1}$ & 323 \\
NMVOC & $\mathrm{g} \cdot \mathrm{GJ}^{-1}$ & 14 \\
Carbon monoxide $^{-1}$ & $\mathrm{~g} \cdot \mathrm{GJ}^{-1}$ & 273 \\
Nitrous oxide $^{\mathrm{a}}$ & $\mathrm{g} \cdot \mathrm{GJ}^{-1}$ & 3.96 \\
Formaldehyde $^{-1}$ & $\mathrm{~g} \cdot \mathrm{GJ}^{-1}$ & 21.15 \\
Sulfur dioxide & $\mathrm{g} \cdot \mathrm{GJ}^{-1}$ & 19 \\
\hline
\end{tabular}

Note: ${ }^{a}$ Including indirect emissions due to $\mathrm{NO}_{\mathrm{x}}$ and ammonia deposition, calculated according to [54].

In manure-fed systems, methane storage emissions (Table 3) were calculated from the data reported by Amon et al. [55] and scaled in proportion to the content of volatile solids in digestate. Applying the same approach, emissions of nitrous oxide and ammonia were calculated as proportional to the actual nitrogen content of the digestate (202 and $141 \mathrm{~kg} \cdot \mathrm{N} \cdot \mathrm{ha}^{-1}$ for maize and sorghum respectively). Nitrogen oxides emissions were estimated according to [54]. Field and storage emission of systems 1o and 1c were calculated as the difference between emissions of the farm system modelled in [11] with and without a biogas plant.

Table 3. Emissions from storage of digestate for open systems.

\begin{tabular}{cccccc}
\hline Emission & Unit & Manure & Maize & Sorghum & References \\
\hline Ammonia & $\mathrm{kg}$ & -216 & 40 & 28 & {$[56]$} \\
Methane & $\mathrm{kg}$ & -18786 & 6748 & 6748 & {$[56]$} \\
$\mathrm{N}_{2} \mathrm{O}$ & $\mathrm{kg}$ & 55 & 117 & 82 & {$[56]$} \\
$\mathrm{NO}_{\mathrm{x}}$ & $\mathrm{kg}$ & -4 & 33 & 23 & {$[54]$} \\
\hline
\end{tabular}

Digestate storage emissions for maize and sorghum systems (open storage) were calculated with the same approach, except for methane emissions which were calculated from the data collected by Weiland et al. [57] for biogas plants running on maize silage.

For the systems employing close tanks, the emissions from storage are assumed to be $2 \%$ of the open digestate storage emissions, mainly associated to the handling of the digestate and maintenance of the tanks.

\section{Results}

\subsection{Life Cycle Impact Assessment (LCIA)}

The inventories of emissions and resources consumed were assessed in terms of environmental impacts, in order to understand and evaluate their magnitude and significance.

\subsubsection{Global Warming Potential}

The impact on global warming was assessed using the IPCC model characterisation factors, also known as Global Warming Potential (GWP) factors, at the 100-year horizon as defined in the IPCC 
AR5 [1]. The unit for the characterisation is $\mathrm{kg} \mathrm{CO}$ eq. For this impact category, we considered only the contribution of the three main long-lived GHGs: carbon dioxide, nitrous oxides (GWP $(100)=298)$ and methane $(\operatorname{GWP}(100)$ fossil methane $=36$, GWP 100 biogenic methane $=34)$. The other substances contributing to this impact have been neglected because their aggregate contribution is less than $0.05 \%$ of the total GHG emissions.

The results of the analysis performed show that the total GHG emissions from manure digestion amount to $-673 \mathrm{gCO}_{2 \mathrm{eq}} \cdot \mathrm{MJ}_{\mathrm{el}}^{-1}\left(-449 \mathrm{gCO}_{2 \mathrm{eq}} \cdot \mathrm{MJ}^{-1}\right.$ el for open digestate storage). The negative values indicate that the avoided emissions from the management of raw manure outmatch by far the emissions caused by the whole biogas pathway (Figure 2(a)). The GHG emissions for systems fed with maize and sorghum with closed storage amount to 130 and $113 \mathrm{gCO}_{2 \mathrm{eq}} \cdot \mathrm{MJ}^{-1}$ el, respectively (197 and $183 \mathrm{gCO}_{2 \mathrm{eq}} \cdot \mathrm{MJ}^{-1}$ el in case of open storage of the digestate). For comparison the data recently published by the European Commission's range between 28 and $62 \mathrm{gCO}_{2 \mathrm{eq}} \cdot \mathrm{MJ}^{-1}$ biogas from maize and -84 and $12 \mathrm{gCO}_{2 \mathrm{eq}} \cdot \mathrm{MJ}^{-1}$ biogas for manure, which, applying the electrical efficiency used in this work, would amount to 74 and $163 \mathrm{gCO}_{2 \mathrm{eq}} \cdot \mathrm{MJ}^{-1}$ el for maize and -263 and $37.5 \mathrm{gCO}_{2 \mathrm{eq}} \cdot \mathrm{MJ}^{-1}$ el for manure [4]). It should be noted that, although the scope and methodology are clearly different, (the most important being the geographical scope, GWPs used and infrastructures not included), the results provide a very similar picture. The processes contributing the most are the biogas engine (it includes the $1 \% \mathrm{CH}_{4}$ leakage from the plant), the emissions from the soil, and emissions from diesel usage and storage emissions; this last process is relevant only for the open systems (Figure 2b). It is noteworthy that emissions from infrastructure construction constitute a share between $7 \%$ and $12 \%$ for the systems based on energy crops.

Concerning substances contribution, methane is the largest contributor to the impact of energy crops systems, accounting for between $41 \%$ and $61 \%$ of the total impact. For manure systems, the emission credits prevail (Figure 2a).

The differences between maize and sorghum are associated mainly with the different level of cultivation inputs. The cultivation of sorghum gives rise to GHG emissions about one third lower than maize because the cultivation of maize requires larger quantities of diesel (for irrigation) and nitrogen fertilisers (the latter also leads to higher $\mathrm{N}_{2} \mathrm{O}$ field emissions).

(a)

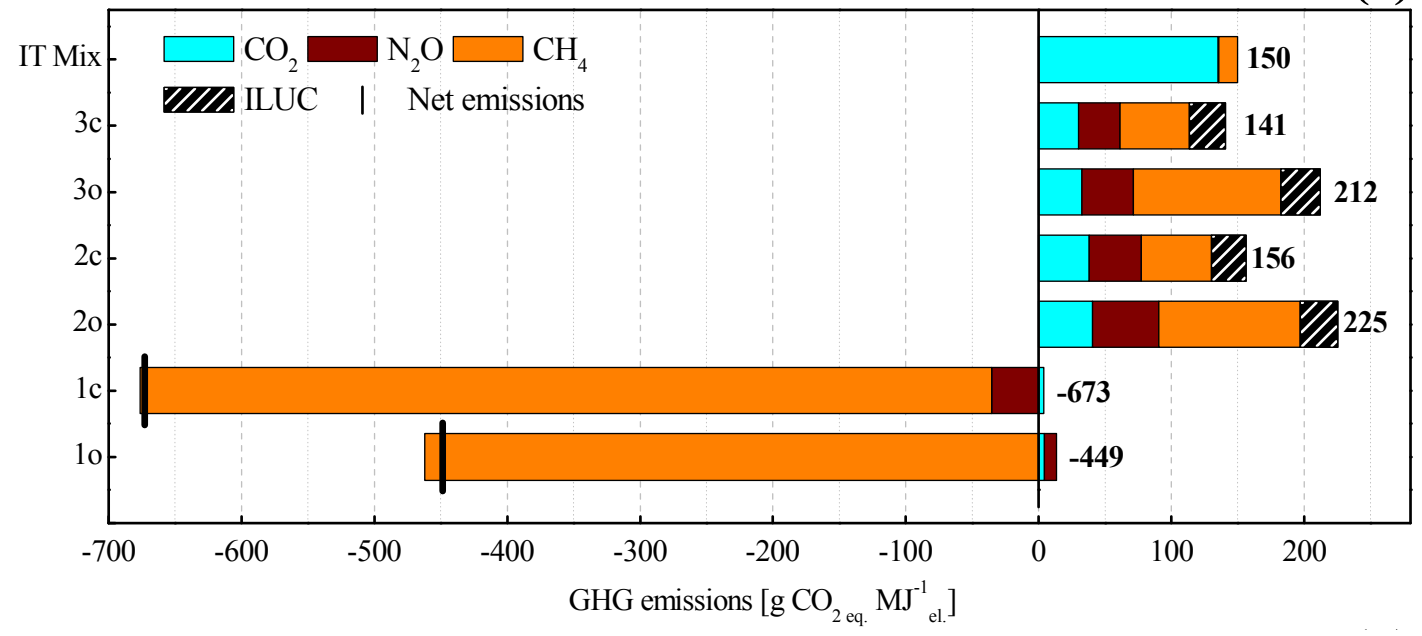

Figure 2. Cont. 


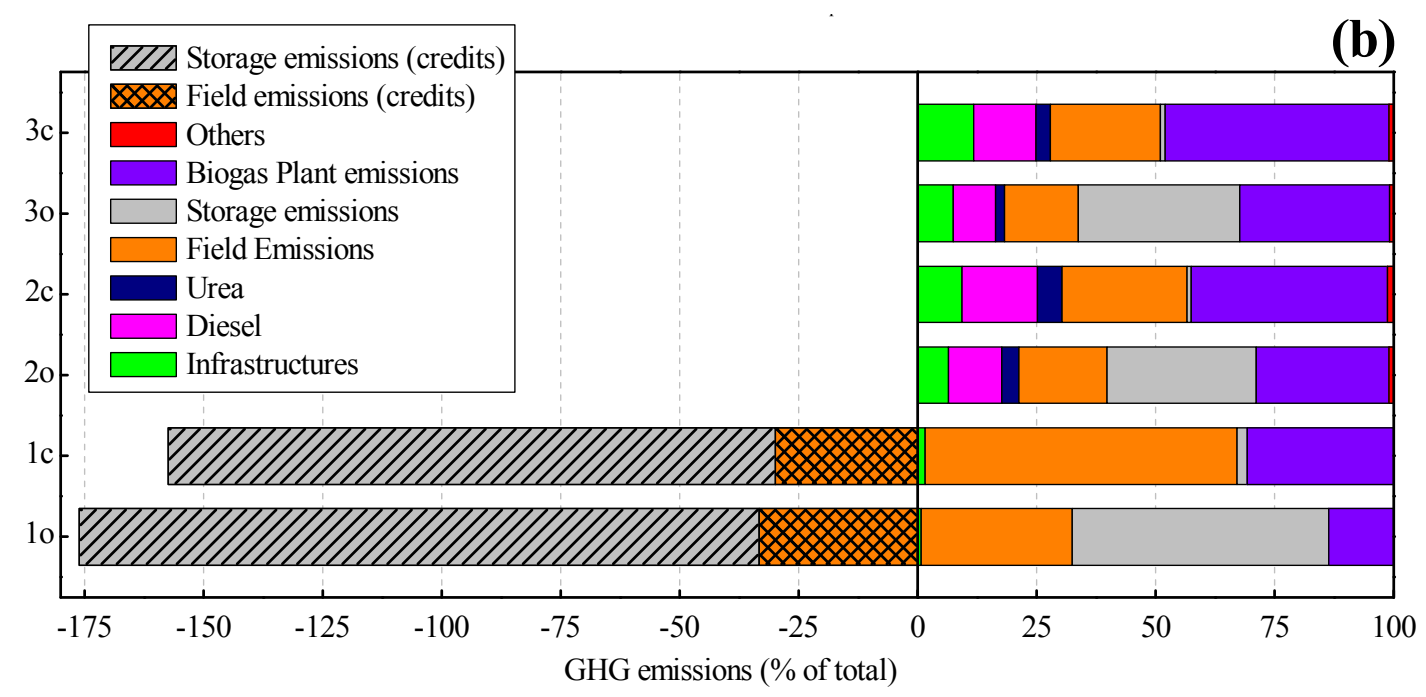

Figure 2. (a) GHG emissions, contribution analysis based on gaseous species (expressed as $\left.\mathrm{g} \cdot \mathrm{CO}_{2 \mathrm{eq}} \cdot \mathrm{MJ}^{-1} \mathrm{el}\right)$. Results of the open-storage (1o, 2o, 3o), the closed-storage (1c, 2c, 3c) and the reference system (i.e., the Italian electricity mix) are included in the graph. Black thick line symbol refers to the net total emissions for the manure pathways. For the energy crops-based systems the GHG emissions associated to ILUC are included as a separate item; (b) Process contribution analysis of the total GHG emissions. The percentage values are referred to the total GHG emissions (ILUC excluded and without credits for manure pathways); for pathway 1o these amount to $589 \mathrm{gCO}_{2 \mathrm{eq}} \cdot \mathrm{MJ}^{-1}$ el, for pathway $1 \mathrm{c}$ to $256 \mathrm{gCO}_{2 \mathrm{eq}} \cdot \mathrm{MJ}^{-1}$ el.

When comparing the conventional (CT) and no-till management (NT), the total GHG emissions decreased by only about $2 \%$ with the NT practice. As explained in the Appendix, soil organic carbon accumulation and the additional $\mathrm{N}_{2} \mathrm{O}$ emissions due to the higher soil microbial activity under NT management are not taken into account.

The results of this study are of the attributional type. They represent a static picture of the system under analysis. However, the results of attributional LCAs are often incorrectly used for macro-scale decisions which affect the installed capacities (e.g., renewable energy policies) [35]. Macro-scale decisions need to be assessed with a consequential modelling approach [31]. For energy crops, several studies have attempted to calculate and integrate the market mediated impacts into the attributional LCA via ILUC modelling [28]. Although integrating ILUC emissions factors into the attributional LCAs is would increase the uncertainty, it does improve the accuracy of the results [58].

With a methodology explained in the Appendix, we have estimated that, the additional emissions accrued by market mediated impacts (ILUC factors) for the systems analysed in this study amount to 28 and $26 \mathrm{gCO}_{2 \mathrm{eq}} \cdot \mathrm{MJ}^{-1}$ for the systems $2 \mathrm{o}$ and $2 \mathrm{c}$, and 29 and $27 \mathrm{gCO}_{2 \mathrm{eq}} \cdot \mathrm{MJ}^{-1}$ el for systems $3 \mathrm{o}$ and $3 \mathrm{c}$, respectively. While including ILUC in the calculation does not affect the GHG emission of the manure-based systems, the GHG emissions of maize and sorghum systems instead, with closed storage, increase to 156 and $141 \mathrm{gCO}_{2 \mathrm{eq}} \cdot \mathrm{MJ}^{-1}$ el respectively (225 and $212 \mathrm{gCO}_{2 \mathrm{eq}} \cdot \mathrm{MJ}^{-1}$ el in case of open storage of the digestate), as shown in Figure 2a.

The use of several substrates in a biogas plant is common practice [3,7,59]; therefore, we have analysed the GHG emissions due to the possible combinations of the three substrates considered in this 
work, and in order to facilitate the interpretation of these results they were compared to the GHG emissions of the Italian electricity mix (150 $\mathrm{gCO}_{2 \mathrm{eq}} \cdot \mathrm{MJel}^{-1}$ [34]). In Figure 3, the GHG emissions for any arbitrary mixture of substrates are reported based on the respective shares in wet mass (as input to the digester) for the open and closed systems. Areas with relevant GHG emissions thresholds are highlighted in the graphs: 0 net $\mathrm{GHG}$ emissions; $45 \mathrm{gCO}_{2 \mathrm{eq}} \cdot \mathrm{MJ}^{-1} \mathrm{el}$, which represents $30 \%$ of the emissions of the Italian electricity mix, $75 \mathrm{gCO}_{2 \mathrm{eq}} \cdot \mathrm{MJ}^{-1}$ el, which represents $50 \%$ of the emissions of the Italian electricity mix; $150 \mathrm{gCO}_{2 \mathrm{eq}} \cdot \mathrm{MJ}^{-1}$ el. which represents the emissions of the Italian electricity mix.

Figure 3 clearly shows that only with a relatively high share of manure in the mixture of substrates the GHG emissions become substantially lower than the Italian electricity mix. The graphs in Figure 3 also show that using sorghum instead of maize may allow the use of a higher share of energy crop to reach the same level of GHG emissions: about 5\% more in case of closed digestate.
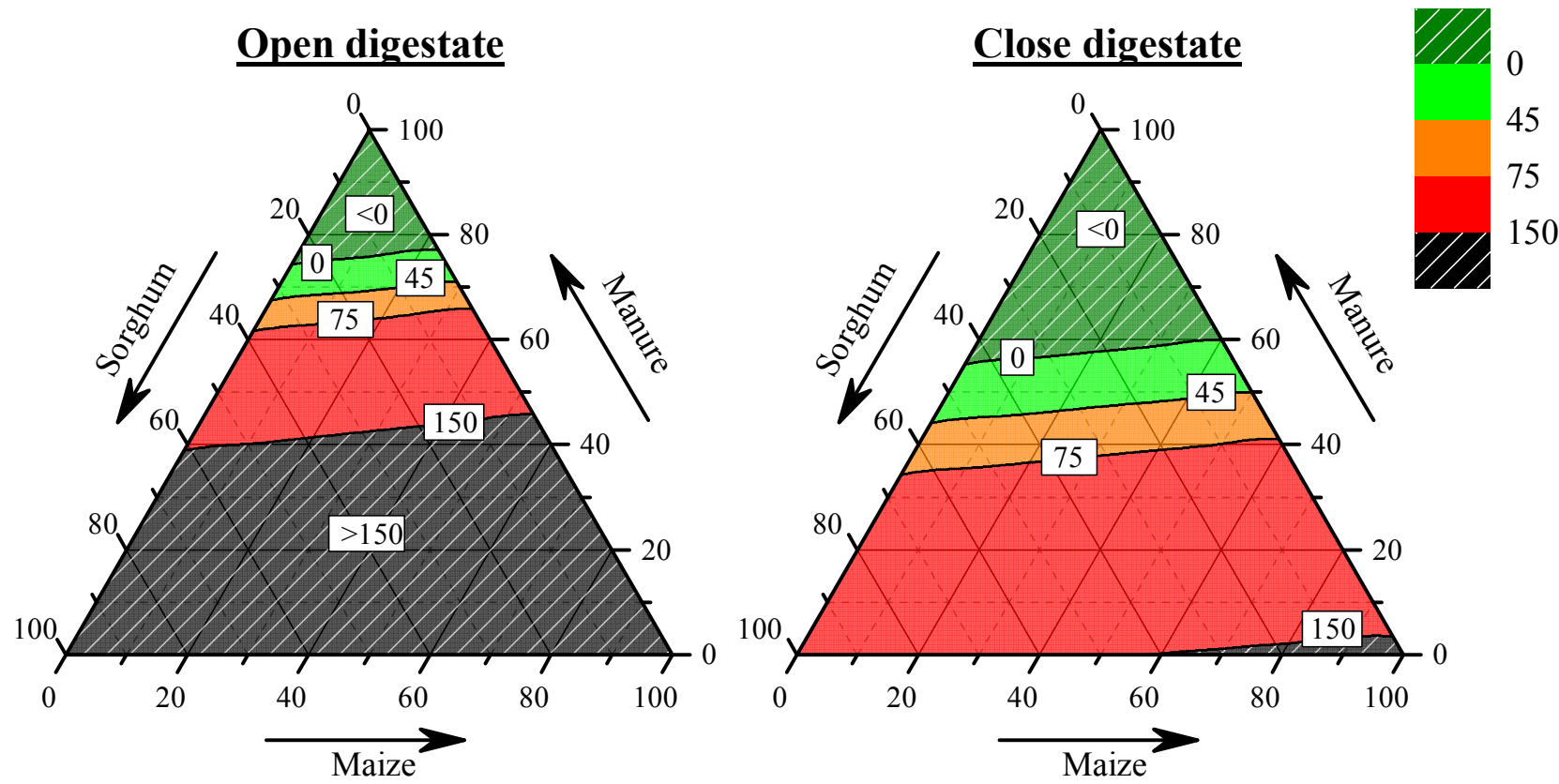

Figure 3. Representation of the GHG emissions resulting from a combination of any mixture of substrates. The shares are reported in wet mass at the input of the digester. To facilitate the interpretation relevant thresholds are highlighted. The green striped area includes systems with negative emissions. The green area represents GHG emissions between 0 and $45 \mathrm{gCO}_{2 \mathrm{eq}} \cdot \mathrm{MJ}^{-1} \mathrm{el}$, (GHG emissions lower than $30 \%$ of the Italian electricity mix). The orange area represents emissions between 45 and $75 \mathrm{gCO}_{2 \mathrm{eq}} \cdot \mathrm{MJ}^{-1} \mathrm{el},(50 \%$ of the Italian electricity mix,). The red area represents emissions between 75 and $150 \mathrm{gCO}_{2 \mathrm{eq}} \cdot \mathrm{MJ}^{-1} \mathrm{el}$, (the GHG emissions of the Italian electricity mix). In the black striped area are included the combinations with emissions higher than the Italian electricity mix.

\subsubsection{Other Environmental Impacts}

The Acidification Potential (AP) is expressed in moles of $\mathrm{H}^{+} \mathrm{eq} \cdot \mathrm{MJ}_{\mathrm{el}}{ }^{-1}$ and it was calculated according to the accumulated exceedance method [60,61]. As shown in Figure 4a, in all the energy crops systems the emissions of ammonia are the largest contributors accounting for a share between $50 \%$ and $60 \%$ of the total impact. In the systems with manure digestion, ammonia emissions were 
practically counterbalanced by the emission credits. The remaining contribution is due to $\mathrm{NO}_{\mathrm{x}}$ and $\mathrm{SO}_{2}$ emissions. Since $\mathrm{NO}_{\mathrm{x}}$ and $\mathrm{SO}_{2}$ are mostly associated to biogas combustion, their amount per $\mathrm{MJ}$ is similar in all scenarios. The main processes contributing to the acidification impact are field emissions for the energy crops followed by biogas engine emissions. Because of the emission credits, in manure- based systems the emissions from the engine were responsible for most of the acidification impact (Figure 4b).

Particulate Matter/Respiratory Inorganics (PM/RI) emissions are expressed in terms of kg PM2.5eq and were calculated according to the intake fraction concept $[62,63]$, using the characterisation factors calculated in for average EU conditions [36]. Figure 4c shows that emissions of ammonia and $\mathrm{NO}_{\mathrm{x}}$ are the main contributors to this impact category because of their role in the formation of secondary particulate matter. Direct emissions of particulate matter account for about $10 \%$ and $20 \%$ of the total impact for manure- and energy crops- based systems, respectively.

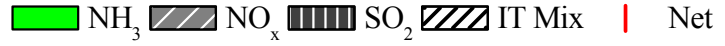

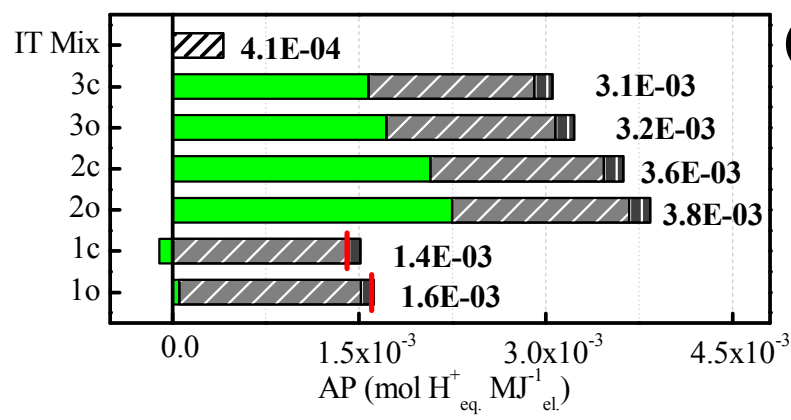

$\square \mathrm{NH}_{3} \measuredangle Z \mathrm{NO}_{\mathrm{x}} \square \mathrm{SO}_{2} \Delta \backslash \nabla$ Dust $\mathrm{ZII}$ IT Mix

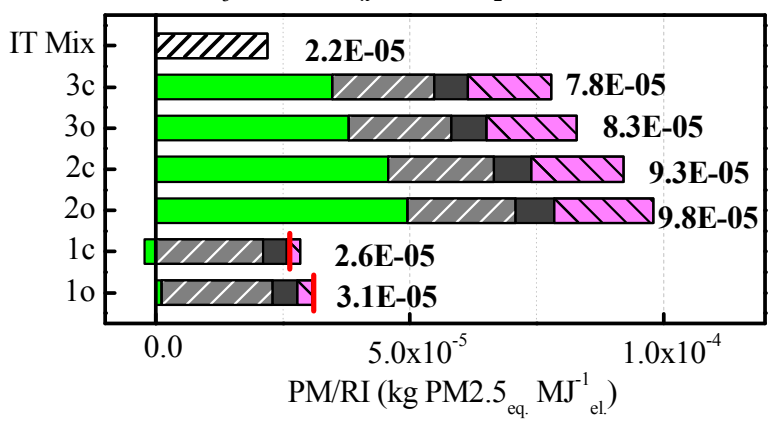

$\square \mathrm{NO}_{\mathrm{x}} \square \mathrm{SO}_{2} \square \mathrm{NMVOC} \square \mathrm{CO} \square \mathrm{CH}_{4}$ VIIJ IT Mix I Net

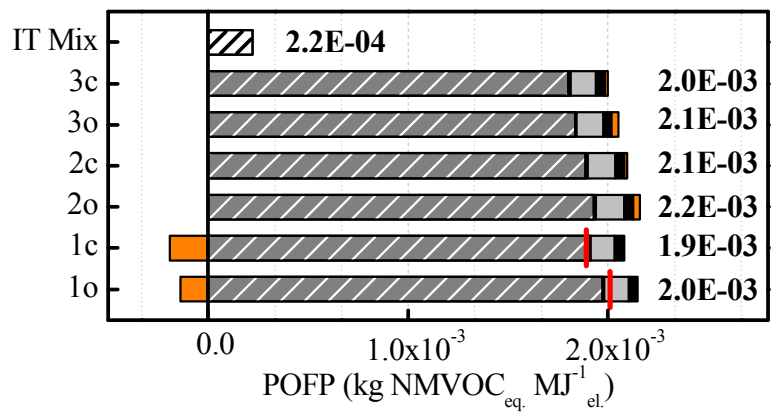

(a)

$\square$ Infrastructure $\square$ Diesel $\square$ Urea $\square$ Storage

$\measuredangle \backslash \backslash$ Field emissions $\square$ Biogas plant $\square$ Others

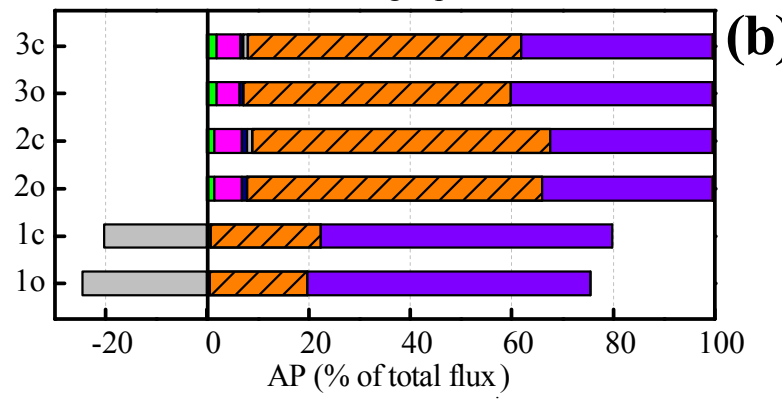

$\square$ Infrastructure $\square$ Diesel $\square$ Urea $\square$ Storage

$Z Z \backslash$ Field emissions $\square$ Biogas plant $\square$ Others

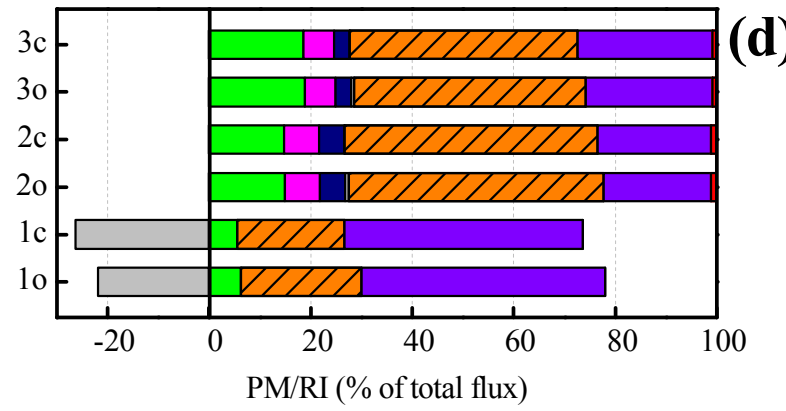

$\square$ Infrastructure $\square$ Diesel $\square$ Urea $\square$ Storage

$\square \backslash \lambda$ Field emissions $\square$ Biogas plant $\square$ Others

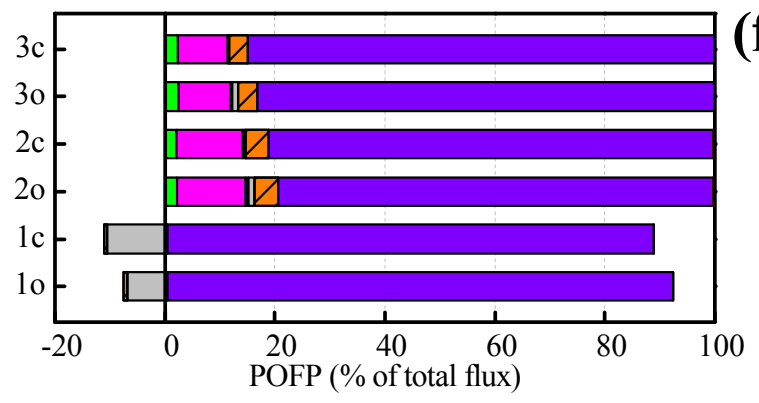

Figure 4. Cont. 

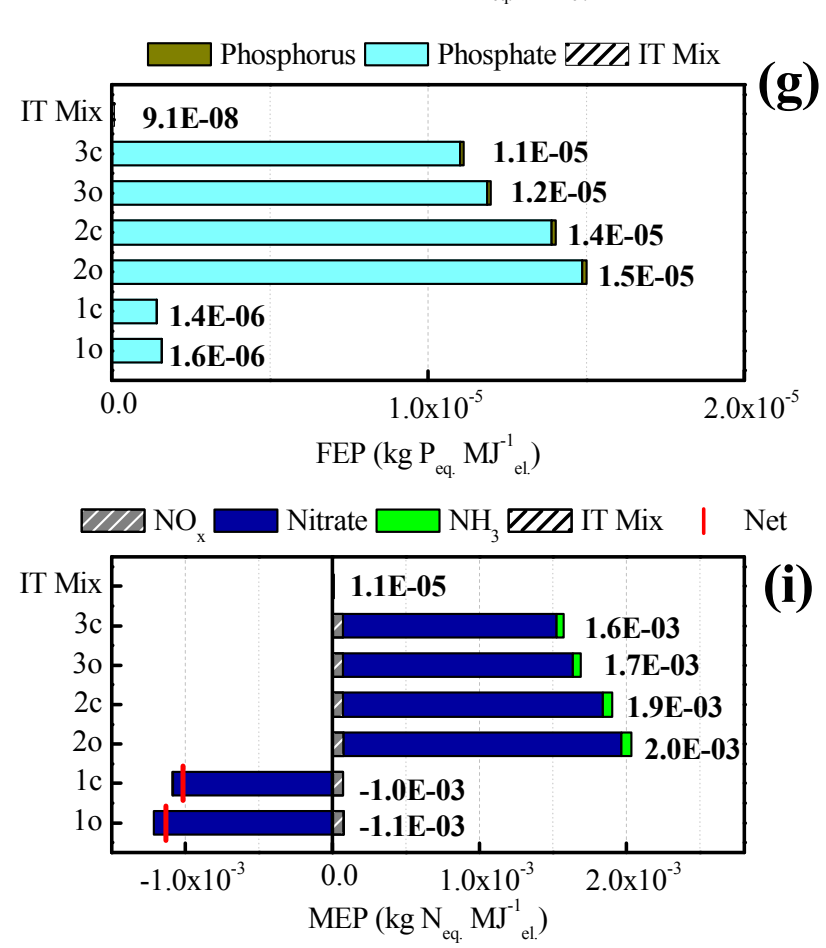

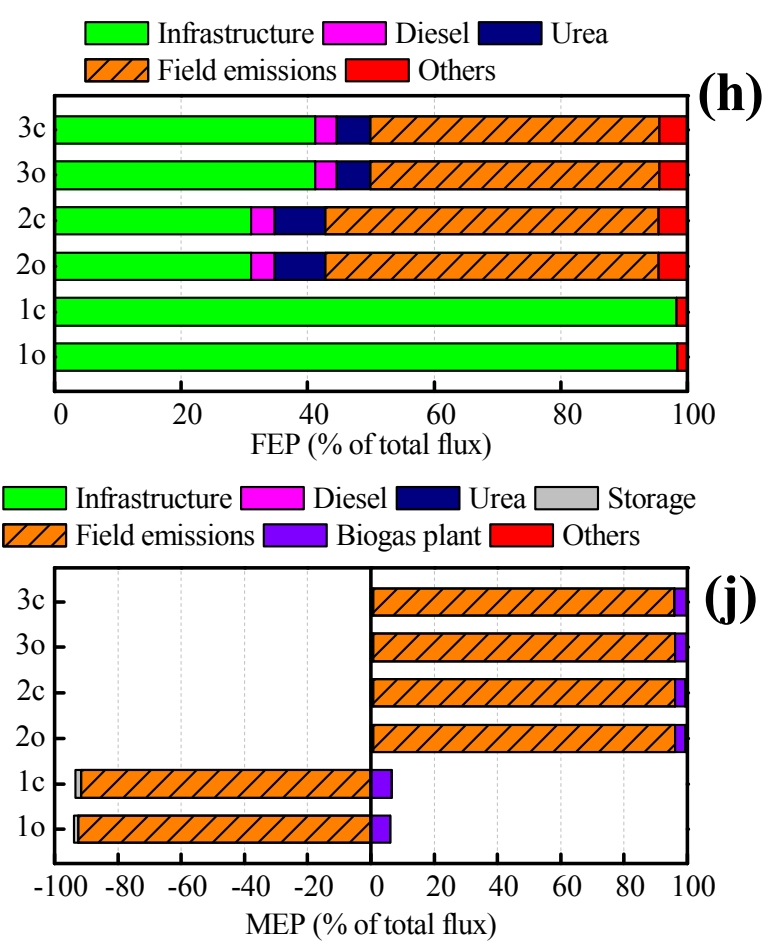

Figure 4. (a) Substances contribution to the Acidification Potential (AP) (in moles of $\mathrm{H}^{+}{ }_{\text {eq }} \cdot \mathrm{MJ}^{-1}$ el). Thick red line symbols represent the net impact for manure pathways; (b) Process contribution for the AP impact. The percentage values are referred to the total fluxes; (c) Substances contribution to Particulate Matter/Respiratory Inorganics (PM/RI) emissions (in $\mathrm{kg} \mathrm{PM} 2.5 \mathrm{eq} \cdot \mathrm{MJ}^{-1}$ el); (d) Process contribution of PM/RI emissions (in \% of the total fluxes); (e) Substances contribution to Photochemical Ozone Formation Potential (POFP) in $\mathrm{kg} \mathrm{NMVOC}$ eq; (f) Process contribution of POFP emissions (in\% of the total fluxes); (g) Substances contribution to Freshwater Eutrophication Potential (FEP) (in $\mathrm{kg} \mathrm{Peq} \cdot \mathrm{MJ}^{-1}$ el.); (h) Process contribution to FEP (in\% of the total fluxes); (i) Substances contribution to Marine Eutrophication Potential (MEP) (in $\mathrm{kg} \mathrm{Neq} \cdot \mathrm{MJ}^{-1}$ el); (j) Process contribution to MEP (in\% of the total fluxes).

The main processes contributing to this impact (Figure 4d) are field emissions for the energy crops due to emissions from synthetic fertilization, while, for manure-based pathways, the field emissionsare practically counterbalanced by the emission credits; therefore the net impact is about equal to the engine emissions. For energy crops systems, the contribution from infrastructures is not negligible, accounting for about $15 \%$ and $19 \%$ of the impact for maize and sorghum systems, respectively.

The Photochemical Ozone Formation Potential (POFP) is expressed in terms of $\mathrm{kg}$ of Non-Methane Volatile Organic Compound equivalent $\left(\mathrm{NMVOC}_{\mathrm{eq}}\right)$ and was calculated according to the method ReCiPe [64]. Figure $4 \mathrm{f}$ shows that this impact is directly related to the combustion processes (mostly in the biogas internal combustion engine); therefore, the emissions are very similar for all the pathways. As shown in Figure 4e, only the manure-based pathways show a lower impact because of the emission credits.

The eutrophication impacts are divided into two categories depending on the ecosystem impacted and the substances responsible. In freshwater ecosystems, phosphorus is the limiting nutrient; therefore, 
only emissions of P-compounds were considered for the assessment of freshwater eutrophication and impacts are expressed in terms of $\mathrm{kg}$ Peq. In sea waters the limiting factor for plant growth is normally $\mathrm{N}$, hence the recommended method includes only $\mathrm{N}$ compounds in the characterization of marine eutrophication [36]. The contributing substances are nitrate, ammonia and nitrogen oxides and the impact is expressed in terms of $\mathrm{kg} \mathrm{Neq}$ [36]. Both categories were calculated according to the method ReCiPe [64].

Figure $4 \mathrm{~g}$ shows that the impact on freshwater eutrophication from biogas plants depends on the amount of phosphorus released into the environment (both as phosphorus and as phosphate) and this is much larger than the reference electricity mix. This is because the emissions of phosphorous for other energy technologies are normally very low compared to agroenergy systems involving the use of mineral or organic fertilisers and a relatively high need of infrastructures. For manure-based pathways, the impact was much lower than for the energy crops systems, and mainly due to emissions associated with construction of the biogas plant (Figure $4 \mathrm{~h}$ ). This is because the emissions of phosphorus do not change if the manure is digested or just stored and spread on the fields.

The potential eutrophication impact on marine ecosystems appears to be equally dependant on nitrate and ammonia emissions in all cases (Figure 4i). Also in this case, the energy crops-based systems, because of the use of mineral and organic fertilisers show a much larger impact compared to the Italian electricity mix. Manure-based biogas production instead presents a reduction of the marine eutrophication due to the lower nitrogen content in the digestate in comparison to the raw manure due to the $\mathrm{N}$ losses during digestion and digestate management.

\subsubsection{Primary Energy from Non-Renewable Resources}

Primary energy from non-renewable sources consumption for the energy crops pathways ranges between 0.44 for sorghum closed digestate to 0.61 for maize open digestate per MJel generated (see Figure 5a). As expected, the primary energy demand from non-renewable resources of manure-based systems is very low, about $0.06 \mathrm{MJ}$ per MJel generated.

In terms of Energy Return over Energy Investment (ERoEI), manure-based pathways perform significantly better than energy crops pathways. The ERoEI calculated are in line with those found by Blengini et al. [13] who also considered the utilisation of the co-generated heat. The main processes contributing to energy demand are the consumption of diesel, infrastructures construction and the production of urea.

In comparison to sorghum, maize shows a greater energy demand due to higher consumption of diesel (especially for irrigation) and nitrogen fertiliser.

\subsubsection{Land Use and Water Consumption}

Regarding land use, the manure pathways have a relatively low impact, because the only land needed is the one occupied by the biogas plant. For maize and sorghum systems the amount of land needed per $\mathrm{MJ}_{\mathrm{el}}$ (Figure 5b) is similar, the main difference being the open or closed storage of the digestate. The systems with closed storage allow for higher biogas utilisation due to the recovery of the digestate off-gases, and therefore less land occupation. 
Manure pathways require almost no water consumption because the substrate is wet enough for anaerobic digestion. Both the energy crops, instead, need water to dilute the ensilaged substrate prior to feeding into the digester. In addition, maize cultivation requires a relatively large amount of water for irrigation (Figure 5c).

(a)

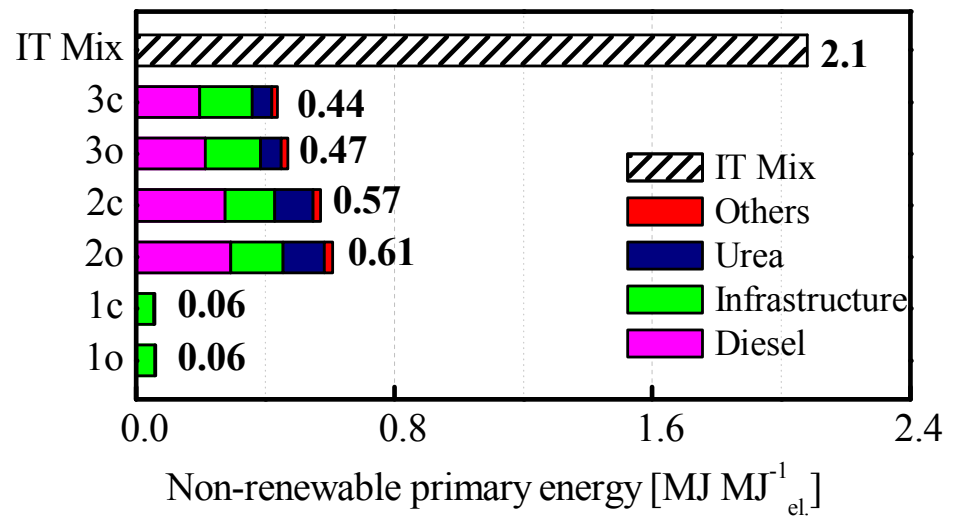

(b)
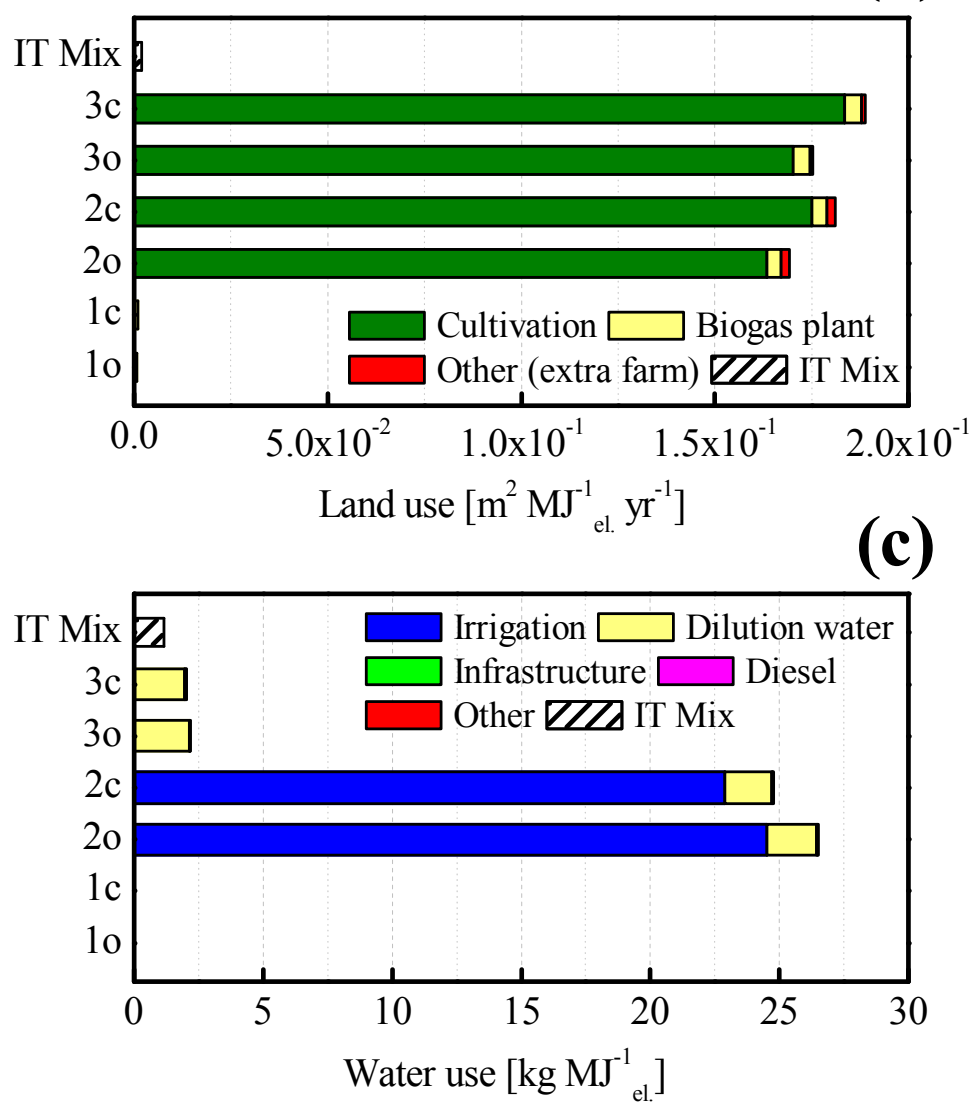

Figure 5. (a) Process contribution analysis of primary energy use from non-renewable sources $\left(\mathrm{MJ} \cdot \mathrm{MJ}^{-1} \mathrm{el}\right)$. Results of the open-storage (1o, 2o, 3o), the closed-storage (1c, 2c, 3c) systems and the reference system (i.e., the Italian electricity mix), are included in the graph. The ERoEI can be calculated as the reciprocal of the primary energy consumption; (b) Land use in the various scenarios in $\mathrm{m}^{2} \cdot \mathrm{yr}^{-1} \cdot \mathrm{MJ}^{-1} \mathrm{el}$; (c) Freshwater consumption in the various scenarios in $\mathrm{kg} \cdot \mathrm{MJ}^{-1}$ el. 


\section{Discussion}

In this work we have analysed the environmental impacts of electricity production via anaerobic digestion of three biogas production Our analysis shows that the introduction of biogas production from dairy farm manure, and its conversion to electricity, decreases significantly the GHG emissions of the farm in absolute terms, thanks to the avoided GHG emissions that would otherwise derive from the management of the raw manure. When biogas is produced from digestion of maize or sorghum silage, the resulting GHG emissions are of the same order of magnitude of the Italian electricity mix.

The exact quantification of ILUC emissions, and their inclusion in attributional LCAs, is still debated in the scientific and policy community. In our case, the share of ILUC emissions over the total GHG emissions of the energy crops systems is limited, ranging between $12 \%$ and $19 \%$ of total impact (see Appendix). This is lower than other crops used for bioenergy, especially oilseed [11,19]. However, they cause the GHG emissions of the bioenergy systems to overtake the psychological threshold represented by the current average electricity mix in Italy. In other cases they may cause the exceeding of specific thresholds for GHG savings.

Considering that biogas from dedicated crops shows poor performance in terms of reducing GHG emissions, the sensitivity of the GWP impact to alternative cultivation techniques was calculated in order to explore eventual strategies to improve GWP performance of these systems. A preliminary analysis of two different methods of cultivation, conventional tillage and no tillage was carried out (and reported in the Appendix) based solely on known and easily quantified effects, such as a reduced diesel consumption in NT operations. This analysis shows that NT cultivation has the potential to improve slightly the system GHG emissions (about $-2 \%$ ). However this analysis is only partial as it does not include Soil Organic Carbon (SOC) changes and $\mathrm{N}_{2} \mathrm{O}$ emissions. A more complete assessment would require consolidated data and models to become available for NT practices on: rate, level and duration of SOC sequestration, physical partitioning of SOC in soil aggregate fractions, evolution of soil aggregate stability, role of microorganisms on SOC humification and stabilization, $\mathrm{N}_{2} \mathrm{O}$ emission dynamics, appropriate nitrogen fertilization [65-67]. Early experimental results indicate that correct implementation of the NT agricultural system (above all, improved use of $\mathrm{N}$ fertilisers) can consolidate the benefits of soil $\mathrm{C}$ sequestration and minimize $\mathrm{N}_{2} \mathrm{O}$ emissions [68-70], potentially making the balance more favourable for the NT practices than what was found in this work.

For the GHG emissions a sensitivity analysis was performed also on the timeframe of the study.

Shortening the assessment of the climate impacts to 20 years, instead of 100, reinforces further our conclusions. Manure has even greater negative emissions, while the energy crops have higher emissions (see Figure A1).

Further analyses were performed to check the sensitivity of our results to the most uncertain data inputs: field emissions, leakages from the plant and storage emissions. The sensitivity was performed only on the GHG emissions, as for the other impacts the biogas systems are a few order of magnitude higher than the Italian electricity mix. The results indicate that, increasing or decreasing by $30 \%$ the emission factors used, the total emissions would not change in a way as to impact the conclusions drawn (see Figure A2-A4). More information is available in the Appendix.

Due to its high yield and digestibility, and its well established cultivation practice, maize is the most common crop substrate for biogas production. However, in order to reach high biomass yields, 
the cultivation of maize requires fertile land and high input of resources, such as fertilisers and water. In areas with low water availability and stringent limits for nitrogen application such as those identified in the Nitrates Directive [71], sorghum represents a valuable alternative crop for bioenergy production. Even if the methane productivity per tonne of fresh matter is lower for sorghum than maize, sorghum may still be competitive with maize thanks to the lower demand for agrochemical inputs. Our study shows, indeed, that for all the environmental impacts studied, sorghum performed better than maize.

Manure-based pathways always show lower impacts than the energy crops-based pathways. However, the environmental impacts associated to the electricity production via manure digestion still result higher than those of the Italian electricity mix. Since a large part of the contribution to many impacts (especially AP, PM/RI and POFP) actually is due to emissions derived from biogas production and combustion, these should be tackled with technological improvements such as higher conversion efficiencies and better combustion technologies to reduce $\mathrm{NO}_{\mathrm{x}}$ and methane slip. This is particularly relevant in the area under analysis given the specific issues of PM concentration and ozone formation in the Po Valley [72].

Emissions of methane from open storage tanks for digestate account for about 3\% of the total methane produced by the energy crops; this value is also in line with the values reported recently by [4]. Total methane emissions from the plants amount to about $5 \%$ of the methane produced for energy crops systems with open storage tanks. In case of closed storage tanks, the methane emissions amount to about $3 \%$ of the total amount of biogas produced. The reduction of these emissions is of paramount importance not only to reduce GHG emissions, but also to improve the economics of the biogas plant. However, this is not always the configuration of many installations in EU.

Manure-based systems perform very well in terms of ERoEI, while, maize and sorghum systems have rather low ERoEI, producing only about twice the amount of energy from non-renewables used. Sorghum, thanks to the lower use of nitrogen fertilisers and diesel for irrigation, performs better than maize. Biogas plants running on manure do not require land for cultivation and water neither for irrigation (as is the case for maize) nor for dilution of the ensiled crops (both maize and sorghum) and, therefore, perform much better than the energy crops also in these areas of concern.

\section{Conclusions}

We conclude that anaerobic digestion and electricity production from manure is an efficient strategy to reduce GHG emissions per se, even though this may be achieved at the expense of other environmental impacts. On the other hand, GHG emissions arising from the generation of electricity using biogas from energy crops are similar to those of the current Italian electricity mix. Moreover, for all the other environmental impact categories (including land use, water and primary energy consumption) the impacts of dedicated bioenergy crops result to be much higher.

If digested alone, energy crops would appear to be environmentally detrimental. However, thanks to their high methane potential, which leads to better economic performances [50], they can be used to increase the attractiveness of anaerobic digestion of manure. However, only a limited fraction of energy crops should be allowed in order to avoid losing the benefits of manure digestion. 
In this study, considering systems with open digestate storage, at least about half of the substrate fed to the plant (by weight in wet mass) should be manure in order to reach a GHG emissions level which is lower than the Italian electricity mix, while, with closed digestate storage, the GHG emissions are similar to those of the electricity mix also without feeding manure to the plant. To reach a GHG saving of $70 \%$ (over the average electricity mix), about $70 \%$ of the substrate should be manure in case of open digestate storage. The share of manure is reduced to about $50 \%$ in case of closed digestate storage. In both cases the share of energy crops may be slightly higher in case sorghum is used instead of maize.

In the case of energy crops co-digestion, the impact of single agronomic practices (i.e., choice of crop type, fertilization, irrigation, no-tillage) seems to have only minor effects on the overall environmental impact of biogas production, especially if compared to the major positive effect achieved by increasing the share of manure or by covering the digestate storage with gas tight membranes.

\section{Author Contributions}

Given the multidisciplinary nature of this work, all eight authors significantly contributed to it with their different points of view and expertise. Alessandro Agostini led the work and performed the analysis, supported by Jacopo Giuntoli. Ferdinando Battini collected and validated the agricultural data. Vincenzo Tabaglio contributed with his expertise on No Till cultivation. Stefano Amaducci supervised the agricultural modelling. Monica Padella and Luisa Marelli provided the analysis of ILUC emissions. David Baxter contributed with his expertise on biogas plants.

\section{Appendix}

\section{Input Values Used for the Cultivation Process}

Maize and sorghum share the same cultivation technique apart from the level of irrigation and fertilization: maize was irrigated three times, while sorghum was grown under rain-fed conditions; maize was fertilized with $120 \mathrm{~kg} \cdot \mathrm{ha}^{-1}$ of nitrogen, while sorghum with only $60 \mathrm{~kg} \cdot \mathrm{ha}^{-1}$. The organic nitrogen in the digestate was 202 and $141 \mathrm{~kg} \cdot \mathrm{N} \cdot \mathrm{ha}^{-1}$ for maize and sorghum respectively.

The inputs shown in Table A1 include not only the cultivation inputs but also those relative to ensiling and desiling operations, digester feeding, on farm digestate transport and spreading. The diesel consumption figures (Table A2) are calculated from the data reported by Bacenetti et al. [8] under similar conditions, but considering lower consumption for some operations (harvest and transport, ensiling and desiling) proportional to the lower yield of silage per hectare considered in this study.

Maize and sorghum average biomass yields (55.2 and $58.0 \mathrm{t} \cdot \mathrm{ha}^{-1}$ respectively) were determined in field trials carried out in Gariga di Podenzano (PC, Po Valley, Northern Italy) at the Vittorio Tadini experimental farm (latitude 44 59') in 2006, 2007, 2008, 2009 and 2010. The genotypes under trial were maize hybrid (Syngenta, NK Arma) and sorghum hybrid (Syngenta, Biomass133). The experiment layout was a split-plot design with four replicates (manuscript in preparation). Tabaglio and Gavazzi [73,74] found, in field trials in the same area, that the yields of maize silage cultivated under CT or NT conditions do not differ significantly. The same assumption is made for sorghum, given its more robust root system. 
Table A1. Input data considered for the cultivation of 1 ha maize and sorghum silage under conventional tillage (CT) and no-tillage (NT).

\begin{tabular}{|c|c|c|c|c|c|c|c|}
\hline Input & Unit & $\begin{array}{l}\text { Maize } \\
(\mathrm{CT})\end{array}$ & $\begin{array}{c}\text { Sorghum } \\
\text { (CT) }\end{array}$ & $\begin{array}{c}\text { Maize } \\
\text { (NT) }\end{array}$ & $\begin{array}{c}\text { Sorghum } \\
(\mathrm{NT})\end{array}$ & Notes & Sources \\
\hline Diesel & $\mathrm{kg} \cdot \mathrm{yr}^{-1}$ & 327.8 & 227.0 & 287.7 & 186.9 & $\begin{array}{c}\text { See Table } 2 \text { for values } \\
\text { disaggregated by operation }\end{array}$ & - \\
\hline Lubricating oil & $\mathrm{kg} \cdot \mathrm{yr}^{-1}$ & 1.87 & 1.30 & 1.64 & 1.07 & $\begin{array}{c}0.008 \text { per } \mathrm{kWh} \text { - Included } \\
\text { disposal and treatment of } \\
\text { waste }\end{array}$ & $\begin{array}{c}\text { Elaborated } \\
\text { from [8] }\end{array}$ \\
\hline Plastic wraps & $\mathrm{kg} \cdot \mathrm{yr}^{-11}$ & 2.5 & 2.5 & 2.5 & 2.5 & $0.11 \mathrm{~kg} / \mathrm{m}^{2}$ for baling & {$[75]$} \\
\hline Urea as N & $\mathrm{kg} \cdot \mathrm{yr}^{-1}$ & 120 & 60 & 120 & 60 & - & Field trials \\
\hline Seed & $\mathrm{kg} \cdot \mathrm{yr}^{-1}$ & 25 & 8 & 25 & 8 & - & Field trials \\
\hline Herbicides & $\begin{array}{l}\text { kg yr }{ }^{-1} \\
\text { a.s. }\end{array}$ & 2.5 & 1,5 & 3.1 & 2.1 & $\begin{array}{c}\text { S-metolaclor }+ \text { Terbutilazine } \\
\text { Glyphosate only for NT }\end{array}$ & Field trials \\
\hline Insecticides & $\begin{array}{l}\mathrm{kg} \cdot \mathrm{yr}^{-1} \\
\text { a.s. }\end{array}$ & 1.13 & 1.13 & 1.13 & 1.13 & Against soil insects & Field trials \\
\hline Machinery & $\mathrm{kg} \cdot \mathrm{yr}^{-1}$ & 39.65 & 32.35 & 35.80 & 28.49 & Average lifetime 12 years & {$[42]$} \\
\hline Machinery shed & $\mathrm{m}^{2} \cdot \mathrm{yr}^{-1}$ & 0.087 & 0.081 & 0.068 & 0.062 & Average lifetime 40 years & {$[42]$} \\
\hline Irrigation water & $\mathrm{m}^{3} \cdot \mathrm{yr}^{-1}$ & 1400 & 0 & 1400 & 0 & $\begin{array}{l}\text { Distributed over three times } \\
\text { for maize }\end{array}$ & Field trials \\
\hline
\end{tabular}

Note: ${ }^{*}$ Values given in $\mathrm{kg}$ of active substance (a.s.).

Table A2. Diesel consumption $\left(\mathrm{kg} \cdot \mathrm{ha}^{-1}\right)$ by tractor and agricultural machinery per each operation during the cultivation and production of silage from maize and sorghum under conventional tillage (CT) and no tillage (NT) (elaborated from Bacenetti et al. [8]).

\begin{tabular}{ccccc}
\hline Operation & Maize $(\mathbf{C T})$ & Sorghum $(\mathbf{C T})$ & Maize $(\mathbf{N T})$ & Sorghum $(\mathbf{N T})$ \\
\hline Digestate transport and spreading & 32.4 & 32.4 & 32.4 & 32.4 \\
Ploughing & 29.5 & 29.5 & 0.0 & 0.0 \\
Harrowing & 21.8 & 21.8 & 0.0 & 0.0 \\
Sowing & 11.2 & 11.2 & 22.4 & 22.4 \\
Chemical weeding & 3.0 & 3.0 & 6.0 & 6.0 \\
Irrigation & 100.8 & 0.0 & 100.8 & 0.0 \\
Mechanical weeding & 3.0 & 3.0 & 0 & 0 \\
Top fertilization & 3.5 & 3.5 & 3.5 & 3.5 \\
Harvesting & 36.3 & 36.3 & 29.3 & 36.3 \\
Chopped crop transport & 29.5 & 29.5 & 29.5 & 29.5 \\
Ensiling & 29.5 & 29.5 & 27.3 & 29.5 \\
Desiling and digester feeding & 27.3 & 27.3 & 287.7 & 27.3 \\
\hline
\end{tabular}

In Table A3 the net field emissions are shown. The field emission of system 1 are calculated as the difference between the emissions of the farm system with and without biogas plant; elementary data are reported in a previous study [11]. 
Table A3. Field emissions (per hectare) due to the application of mineral and organic fertilisers.

\begin{tabular}{ccccccc}
\hline Emissions & Unit & Manure & Maize & Sorghum & Source & References \\
\hline Methane & $\mathrm{kg}$ & 0.065 & 0.33 & 0.35 & Digestate & {$[55]$} \\
Nitrous oxide & $\mathrm{kg}$ & -0.51 & 6.97 & 5.14 & Digestate and urea & {$[54,76]$} \\
Ammonia & $\mathrm{kg}$ & 3.17 & 41.32 & 30.34 & Digestate and urea & {$[54,77]$} \\
Nitrogen oxides & $\mathrm{kg}$ & -0.24 & 5.45 & 3.96 & Digestate and urea & {$[76,78]$} \\
Nitrate leaching & $\mathrm{kg} \mathrm{N}$ & -18.88 & 104.99 & 83.42 & N surplus & {$[79]$} \\
Phosphate run-off & $\mathrm{kg} \mathrm{P}$ & 0 & 0.45 & 0.30 & Digestate & {$[80,81]$} \\
\hline
\end{tabular}

Emissions from diesel (Table A4) used on the farm are based on data reported by Winther and Nielsen [82].

Table A4. Diesel emissions per ton of diesel combusted (elaborated from [82]).

\begin{tabular}{ccc}
\hline Emissions & Unit & Quantity \\
\hline Methane & $\mathrm{kg}$ & 0.07 \\
$\mathrm{CO}_{2}$ & $\mathrm{~kg}$ & 3187.8 \\
$\mathrm{~N}_{2} \mathrm{O}$ & $\mathrm{kg}$ & 0.13 \\
$\mathrm{NO}_{\mathrm{x}}$ & $\mathrm{kg}$ & 37.9 \\
$\mathrm{NH}_{3}$ & $\mathrm{~kg}$ & $6.4 \times 10^{-3}$ \\
$\mathrm{SO}_{2}$ & $\mathrm{~kg}$ & 1.01 \\
$\mathrm{NMVOC}$ & $\mathrm{kg}$ & 4.3 \\
$\mathrm{CO}$ & $\mathrm{kg}$ & 20.5 \\
$\mathrm{TSP}$ & $\mathrm{kg}$ & 3.2 \\
\hline
\end{tabular}

\section{Assessment of the GHG Emissions from Conventional Tillage (CT) and No-tillage (NT) Practices}

The CT management is based on ploughing at a depth of $40 \mathrm{~cm}$, followed by harrowing and sowing. The NT management alternative consisted of direct sowing after herbicide treatment (Glyphosate). The analysis should also consider the impact of Soil Organic Carbon (SOC) accumulation; however, data availability for long term empirical research is scarce and results are highly variable and site specific [66,83-87].

In a recent review, Abdalla et al. [65] have found that no- tillage practices can, under appropriate conditions, enhance SOC accumulation. On the other hand, they found also that adopting conservative tillage practices may enhance $\mathrm{N}_{2} \mathrm{O}$ emissions.

In both cases, the studies reported very scattered and conflicting results, mostly because of the great impact on GHG emissions of climate and soil type and management practices. Furthermore, beside the heterogeneity of the experimental conditions, Derpsch et al. [68] have identified a need for standardization of experimental conditions for an appropriate comparison between conventional and conservative tillage systems especially with respect to $\mathrm{N}$ fertiliser use, tillage systems and duration of the trials. Given the difficulty in quantifying the impacts on SOC accumulation and $\mathrm{N}_{2} \mathrm{O}$ emissions of no-tillage practices, we have limited our analysis to the differences between the two management practices which are easily quantifiable: the amount of diesel and infrastructures (farm machinery and related shed) saved by the no-tillage system. These differences in infrastructures and diesel fuel consumption are reported in Tables A1 and A2. 
When comparing the conventional and no-till management, the GHG emissions for cultivation per hectare decreased by $9 \%$ for maize (from 1926 to $1757 \mathrm{~kg} \mathrm{CO}_{2 \mathrm{eq}}$ ) and by $13 \%$ for sorghum (from 1270 to $1101 \mathrm{~kg} \mathrm{CO} 2 \mathrm{eq})$.

As cultivation accounted for less than one fourth of the total GHG emissions $(17 \%$ and $24 \%$ of the total GHG emissions from maize with open and closed digestate storage, respectively, 13\% and 19\% respectively for sorghum; the higher share in closed systems is due to the lower total emissions), limited GHG savings could be achieved by adopting the NT instead of the CT management; the total GHG emissions decreased by only about $2 \%$ (1.5\% and $2.1 \%$ for maize with open and closed digestate storage, while the same reduction was $1.7 \%$ and $2.5 \%$ for sorghum). These results however have limitations because of missed accounting of soil organic carbon accumulation and the additional $\mathrm{N}_{2} \mathrm{O}$ emissions due to the higher soil microbial activity under NT management.

As regards the primary energy consumption from non-renewables (based on net calorific value) for the cultivation of one hectare results to be equal to 28,380 MJ and 26,079 MJ for maize CT and NT, respectively, and to 18,635 $\mathrm{MJ}$ and 16,334 $\mathrm{MJ}$ for sorghum $\mathrm{CT}$ and $\mathrm{NT}$, respectively. The adoption of a NT practice leads to a reduction in primary energy demand from non-renewables in the cultivation process because of the lower diesel consumption ( $8 \%$ less diesel for maize and $12 \%$ for sorghum). The total primary energy consumption from non-renewables decreased by $7 \%$ for maize and $9 \%$ for sorghum when a NT management system was adopted.

\section{Carbon Emissions from ILUC}

ILUC occurs when land used for a food/feed/fibres crop is diverted to the production of biofuels/bioenergy. To maintain the level of food/feed/fibres production, cultivation of the displaced crop may be carried out in other locations (e.g., converting grasslands or forested lands into agricultural land) and/or with an intensification of agricultural production techniques and decreased consumption.

Converting land cover types with high biomass and soil carbon stocks (such as grasslands and forested land) into cropland may result in the release of carbon stored in above and below-ground biomass (vegetation), and in the soil, thus GHG are emitted. In assessing the impact of biogas production from maize and sorghum on the release of GHG, indirect Land use Change (ILUC) emissions should be taken into account [28,30,88]. Although estimations of ILUC emissions are subject to the intrinsic uncertainty of land use and market models, the EC has acknowledged that ILUC can reduce the GHG savings associated with bioenergy, and therefore recommended that this issue is to be addressed under a precautionary approach [89].

The biogas production systems in this study involve a farm of 75 ha. If this area is used for the cultivation of energy crops, ILUC emissions due to the displacement of the dairy cows feed production, caused by the appropriation of land for energy purposes, have to be accounted for. In this work it is assumed that the diversion of 1 ha of land suitable for maize cultivation from food or feed production to energy production, generates the same ILUC emissions irrespective of whether the final conversion is to biogas or ethanol.

For this purpose, the ILUC emission coefficients calculated with the economic model MIRAGE [90] run by the International Food and Policy Research Institute (IFPRI), were used. IFPRI-MIRAGE is the 
EC reference model used to estimate the indirect land use change emissions included in the policy proposal COM(2012)595 [89]. In the case of ethanol from maize, the IFPRI-MIRAGE model estimated ILUC emissions equal to $10 \mathrm{gCO}_{2 \mathrm{eq}} \cdot \mathrm{MJ}^{-1}$ EtOH [90].

All economic models used for ILUC assessment (including IFPRI-MIRAGE) assume that the increase in land occupation driven by biofuels demand may be partly compensated by yield increase and reduced food consumption due to the crops price increase and by the return of by-products to the animal feed sector [88]. The use of by-products from biofuels production as animal feed avoids additional feed production; hence the need of cropland area expansion and the total ILUC GHG emissions are reduced. This reduction cannot be applied when maize is used for biogas, since no by-products are generated. Consequently, for the purpose of this study, we extrapolated the contribution of by-products in reducing the ILUC emissions of maize by applying a 'decomposition' methodology developed by the Joint Research Centre of the European Commission [88] to the results of MIRAGE model [28], estimating the amount of land attributed to by-products use.

Starting from the increased area of maize devoted to ethanol production, the "decomposition" approach identifies the sources from which models generally derive land, besides cropland expansion. These are: substitution of animal-feed crops with by-products of biofuel production; reduction in crop consumption in competing uses (mostly food) and land freed up by additional yield gains, both induced by higher crop prices (as a result of increased crop demand for biofuels).

The "decomposition approach" applied to IFPRI-MIRAGE model showed that the replacement of animal feed crops by biofuels by-products corresponds to about $36 \%$ of the total area increase due to the additional biofuel demand. Therefore, the ILUC emission coefficient for maize in [90] has been increased accordingly, resulting in a final value of $15.7 \mathrm{gCO}_{2 \mathrm{eq}} \cdot \mathrm{MJ}^{-1} \mathrm{EtOH}$.

In another study recently carried out by the JRC in collaboration with IFPRI [91], the MIRAGE model was run with a scenario in which co-products from marginal biofuel are not injected in the livestock sector. If by-products are not produced, the livestock sector has to rely more on other crops, thus increasing ILUC. This scenario resulted in an ILUC coefficient of $15 \mathrm{gCO}_{2 \mathrm{eq}} \cdot \mathrm{MJ}^{-1} \mathrm{EtOH}$ for maize, (the value used for this study) in perfect agreement with the result of the decomposition approach.

ILUC emissions per MJ of maize ethanol estimated with the above methodologies have been further converted into emissions per ha of maize, using the average dry maize grain yield for the area where the farm is located $\left(10,300 \mathrm{~kg}_{\text {maize grain }} \cdot \mathrm{ha}^{-1}\right)$ and the following input data from [92]: maize grain moisture $=14 \%$; maize grain energy content (Lower Heating Value) $=17.3 \mathrm{MJ} \cdot \mathrm{kg}^{-1}$ dry; losses handling $=1 \%$; losses transport $=0.81 \%$; ethanol yield $=0.606 \mathrm{MJ}_{\mathrm{EtOH}} \cdot \mathrm{MJ}^{-1}$ maize grain. The resulting ILUC is thus equal to $1595 \mathrm{kgCO} 2 \mathrm{eq} \cdot \mathrm{ha}^{-1}$ that, multiplied by cultivated area and divided by the total electricity produced by the biogas plant, generates additional emissions of 28 and $26 \mathrm{gCO}_{2 \mathrm{eq}} \cdot \mathrm{MJ}^{-1}$ for the systems $2 \mathrm{o}$ and $2 \mathrm{c}$, and 29 and $27 \mathrm{gCO}_{2 \mathrm{eq}} \mathrm{MJ}^{-1}$ el for systems $3 \mathrm{o}$ and $3 \mathrm{c}$, respectively. Including ILUC in the calculation does not affect the GHG emission of the manure based systems. For maize and sorghum systems instead, GHG emissions, with closed storage, increase to 156 and $141 \mathrm{gCO}_{2 \mathrm{eq}} \cdot \mathrm{MJ}^{-1}$ el respectively (225 and $212 \mathrm{gCO} 2 \mathrm{eq} \cdot \mathrm{MJ}^{-1}$ el in case of open storage of the digestate). Using other economic models may result in different estimates and surely the ILUC emission values used in this work are subject to uncertainty; nevertheless they may offer a good estimate of the order of magnitude of the phenomenon. 


\section{Impact of Timeframe Choice on GHG Emission Assessment}

As reported by the IPCC [8], several metrics are available for the assessment of the impacts of GHG emission on climate change. There is no better metric, different metrics answer different questions. The most common is the Global Warming Potential (GWP), the metric used also by United Nations Framework Convention on Climate Change (UNFCC) for the Kyoto protocol targets. The GWP is a relative cumulative metric, it measures the total impact of a GHG species in the atmosphere, in a given timeframe, relative to a reference $\mathrm{GHG},\left(\mathrm{CO}_{2}\right)$.

Given the short lifetime of methane in the atmosphere, we have analysed the effect of choosing a shorter timeframe for this assessment. According to the IPCC [8], the GWP of biogenic methane, in a 20 year timeframe, is 86 instead of 34 ( 87 and 36 for the fossil methane). For laughing gas $\mathrm{N}_{2} \mathrm{O}$, the value decreases from 298 to 268. The results are reported in Figure A1.

The results show that in a shorter timeframe, the benefits of manure digestion are more than twice of those of a 100 year timeframe. This is mostly due to high amount of methane emissions avoided and the short half-life of methane in the atmosphere, (12.4 years [8]). The GWP of $\mathrm{N}_{2} \mathrm{O}$ instead, with its long half-life (121 years), does not change dramatically. This sensitivity analysis shows that in a shorter timeframe, manure digestion is even more effective in fighting climate change. Instead, for the energy crops, the GHG emission results always higher than the Italian electricity mix, almost twice for the systems with open storage of the digestate, mostly because of the high methane emissions.

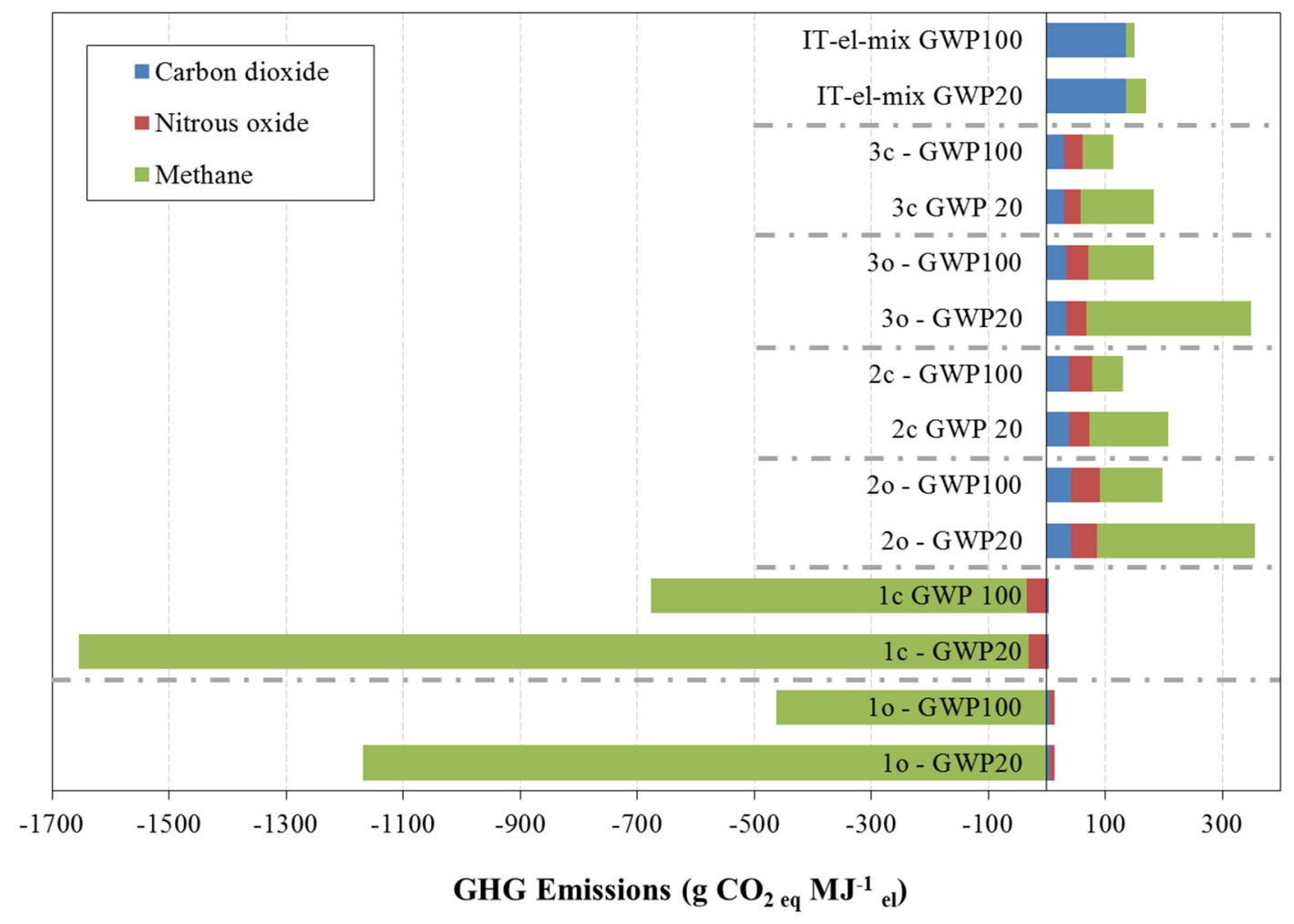

Figure A1. GHG emissions, contribution analysis based on gaseous species (expressed as ( $\left.\mathrm{g} \mathrm{CO}_{2 \mathrm{eq}} \cdot \mathrm{MJ}^{-1} \mathrm{el}\right)$. Results of the open-storage (1o, 2o, 3o), the closed-storage (1c, 2c, 3c) and the reference system (i.e., the Italian electricity mix) for a 20 years (GWP20) and 100 years (GWP100) timeframe. 


\section{Sensitivity to Manure and Digestate Storage Emissions}

Emissions from the storage of manure depend on several factors: manure type, storage temperature, storage duration, aeration, and formation of a natural crust at the surface of slurry, to name the most important ones. In this work the field emissions for manure digestion are taken from Battini et al. [78].

However, given their uncertainty and the dominant effect on the GHG emissions, especially in case of codigestion, we have carried out a sensitivity analysis varying them by + or $-30 \%$. For consistency, the digestate storage emissions were increase or reduced of the same percentage.

The results are reported in Figure A2. It is worth nothing that the GHG emissions of energy crops based systems still are similar to the Italian electricity mix (those with closed digestate storage are practically not affected at all). The plants running on manure are strongly affected, however they provide absolute high GHG savings in any case.

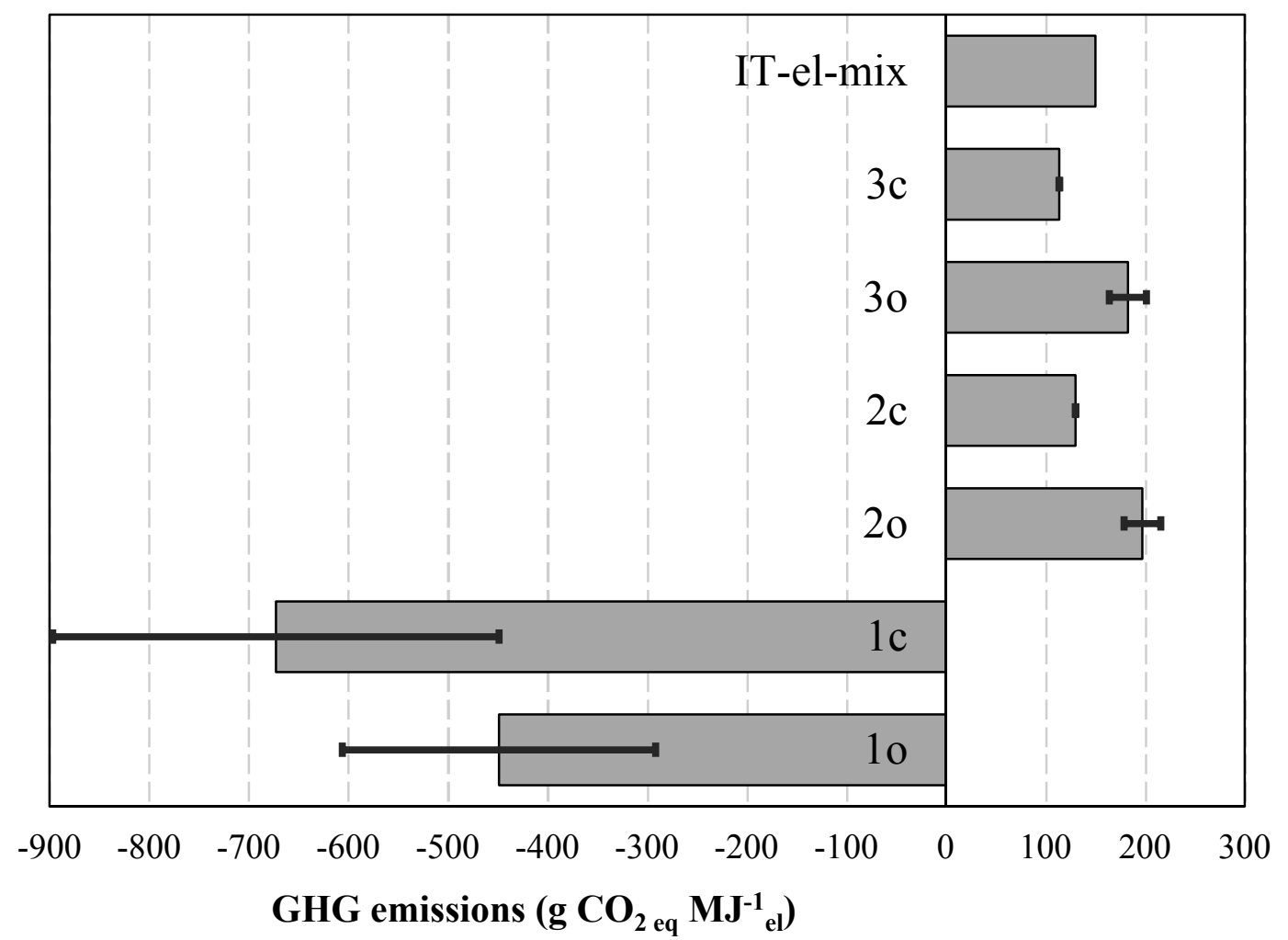

Figure A2. Results of the assessment of the sensitivity of the total GHG emissions to the variability of digestate and manure storage emissions. The grey bars represent the total GHG emissions of the analysed systems, the black error bars represent how the total GHG emissions range by varying the storage emissions by + or $-30 \%$.

\section{Sensitivity to Biogas Plant Leakages and Methane Slip from the CHP}

Emissions from the biogas plants are highly variable as they depend both on the technology adopted, but also to the level maintenance and leaks detection [52]. Some leakages, e.g., the methane slip from the CHP plant, are unavoidable in lean burn combustion, unless technologies for the post treatment of the off-gases are adopted. Other leakages are accidental, often due to leaky gaskets, 
membranes and other infrastructural component permeability or leaks. They are therefore highly uncertain. We have carried out a sensitivity analysis varying them by + or $-30 \%$.

The results are reported in Figure A3. It is worth nothing that also in this case the results are only slightly affected by the assumptions made on the leakages from the biogas plant and the methane slip through the engine.

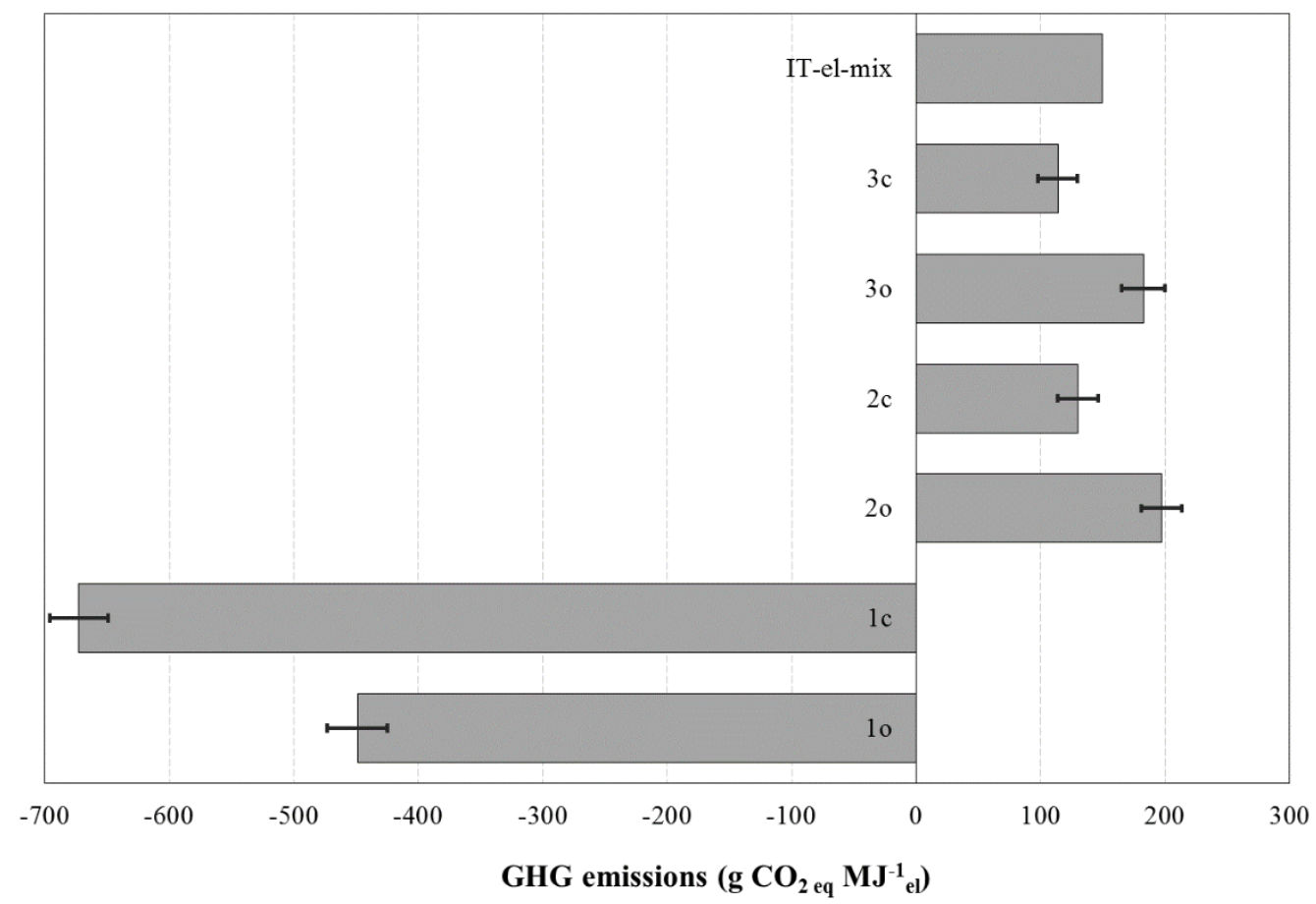

Figure A3. Results of the assessment of the sensitivity of the total GHG emissions to the variability of biogas plants leakages and methane slip through the gas engine. The grey bars represent the total GHG emissions of the analysed systems, the black error bars represent how the total GHG emissions range by varying the leakages and the methane slip by + or $-30 \%$.

\section{Sensitivity to Field Emissions}

Emissions from the application of fertilizers (both mineral and organic) are highly variable and depend on several factors: fertilizers type, timing of the application, climatic conditions during the application and the following days, soil properties, to name the most important ones. The references used in this work are detailed in Table A3.

To assess the robustness of the results of this study, we have varied the field emissions of + and $30 \%$ of their value. The results are reported in Figure A4. Clearly the conclusions do not change. Energy crops-based systems have about the same emissions as the Italian electricity mix, while manure-based systems provide absolute GHG savings. 


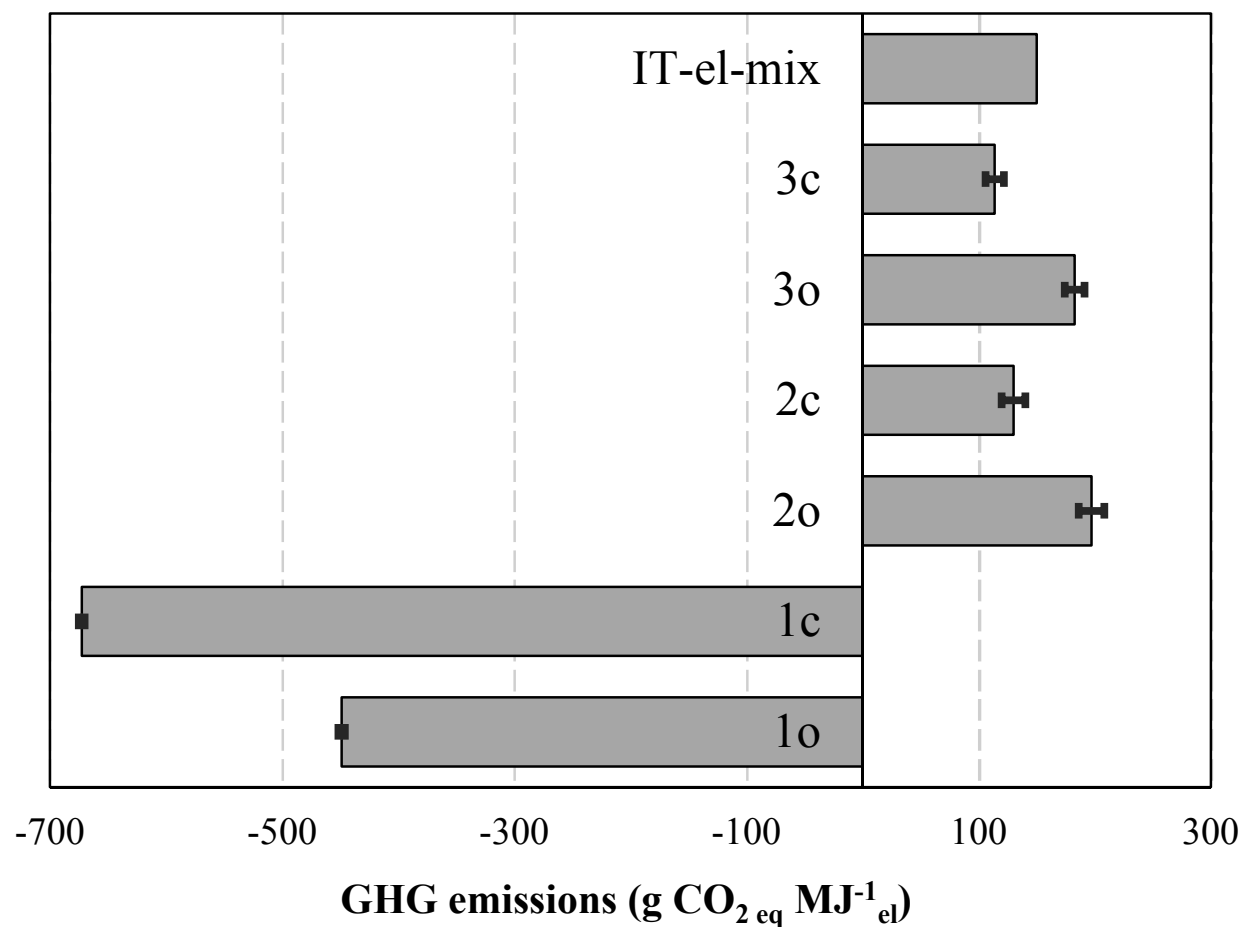

Figure A4. Results of the assessment of the sensitivity of the total GHG emissions to the variability of field emissions. The grey bars represent the total GHG emissions of the analysed systems, the black error bars represent how the total GHG emissions range by varying the field emissions by + or $-30 \%$.

\section{Conflicts of Interest}

The authors declare no conflict of interest.

\section{References}

1. Climate Change 2013: The Physical Science Basis. Contribution of Working Group I to the Fifth Assessment Report of the Intergovernmental Panel on Climate Change; Stocker, T.F., Qin, D., Plattner, G.-K., Tignor, M., Allen, S.K., Boschung, J., Nauels, A., Xia, Y., Bex, V., Midgley, P.M., Eds.; Cambridge University Press: New York, NY, USA, 2013; p. 1535.

2. Report from the Commission to the Council and the European Parliament on Sustainability Requirements for the Use of Solid and Gaseous Biomass Sources in Electricity, Heating and Cooling; European Commission: Brussels, Belgium, 2010.

3. Swd(2014)259-State of Play on the Sustainability of Solid and Gaseous Biomass Used for Electricity, Heating and Cooling in the EU; European Commission: Brussels, Belgium, 2014.

4. Giuntoli, J.; Agostini, A.; Edwards, R.; Marelli, L. Solid and Gaseous Bioenergy Pathways: Input Values and GHG Emissions; European Commission, Joint Research Centre: Ispra, Italy, 2015.

5. Mela, G.; Canali, G. How distorting policies can affect energy efficiency and sustainability: The case of biogas production in the Po Valley (Italy). AgBioForum 2014, 16, 194-206. 
6. Decreto 6 Luglio 2012: Attuazione Dell'art. 24 del Decreto Legislativo 3 Marzo 2011, n. 28, Recante Incentivazione Della Produzione di Energia Elettrica da Impianti a Fonti Rinnovabili Diversi dai Fotovoltaici; Ministero dello Sviluppo Economico: Rome, Italy, 2012. (In Italian)

7. Fabbri, C.; Labartino, N.; Manfredi, S.; Piccinini, S. Biogas, il settore è strutturato e continua a crescere. L'Infor. Agrar. 2013, 11, 11-18. (In Italian)

8. Bacenetti, J.; Fusi, A.; Negri, M.; Guidetti, R.; Fiala, M. Environmental assessment of two different crop systems in terms of biomethane potential production. Sci. Total Environ. 2014, 466-467, 1066-1077.

9. Capponi, S.; Fazio, S.; Barbanti, L. $\mathrm{CO}_{2}$ savings affect the break-even distance of feedstock supply and digestate placement in biogas production. Renew. Energy 2012, 37, 45-52.

10. Gerin, P.A.; Vliegen, F.; Jossart, J.-M. Energy and co2 balance of maize and grass as energy crops for anaerobic digestion. Bioresour. Technol. 2008, 99, 2620-2627.

11. Battini, F.; Agostini, A.; Boulamanti, A.K.; Giuntoli, J.; Amaducci, S. Mitigating the environmental impacts of milk production via anaerobic digestion of manure: Case study of a dairy farm in the Po Valley. Sci. Total Environ. 2014, 481, 196-208.

12. Boulamanti, A.K.; Donida Maglio, S.; Giuntoli, J.; Agostini, A. Influence of different practices on biogas sustainability. Biomass Bioenergy 2013, 53, 149-161.

13. Blengini, G.A.; Brizio, E.; Cibrario, M.; Genon, G. LCA of bioenergy chains in Piedmont (Italy): A case study to support public decision makers towards sustainability. Resour. Conserv. Recycl. 2011, 57, 36-47.

14. González-García, S.; Bacenetti, J.; Negri, M.; Fiala, M.; Arroja, L. Comparative environmental performance of three different annual energy crops for biogas production in Northern Italy. J. Clean. Prod. 2013, 43, 71-83.

15. Lansche, J.; Müller, J. Life cycle assessment of energy generation of biogas fed combined heat and power plants: Environmental impact of different agricultural substrates. Eng. Life Sci. 2012, 12, 313-320.

16. Lijó, L.; González-García, S.; Bacenetti, J.; Fiala, M.; Feijoo, G.; Lema, J.M.; Moreira, M.T. Life cycle assessment of electricity production in Italy from anaerobic co-digestion of pig slurry and energy crops. Renew. Energy 2014, 68, 625-635.

17. Lijó, L.; González-García, S.; Bacenetti, J.; Fiala, M.; Feijoo, G.; Moreira, M.T. Assuring the sustainable production of biogas from anaerobic mono-digestion. J. Clean. Prod. 2014, 72, $23-34$.

18. Whiting, A.; Azapagic, A. Life cycle environmental impacts of generating electricity and heat from biogas produced by anaerobic digestion. Energy 2014, 70, 181-193.

19. Berndes, G. Bioenergy and water-The implications of large-scale bioenergy production for water use and supply. Glob. Environ. Chang. 2002, 12, 253-271.

20. Gheewala, S.H.; Berndes, G.; Jewitt, G. The bioenergy and water nexus. Biofuels Bioprod. Biorefin. 2011, 5, 353-360.

21. Climate Change 2013: Impacts, Adaptation, and Vulnerability. Contribution of Working Group II to the Fifth Assessment Report of the Intergovernmental Panel on Climate Change; Field, C.B., Barros, V.R., Dokken, D.J., Mach, K.J., Mastrandrea, M.D., Bilir, T.E., Chatterjee, M., Ebi, K.L., Estrada, Y.O., Genova, R.C., et al. Eds.; Cambridge University Press: New York, NY, USA, 2014; p. 1132. 
22. Amaducci, S.; Amaducci, M.T.; Benati, R.; Venturi, G. Crop yield and quality parameters of four annual fibre crops (hemp, kenaf, maize and sorghum) in the north of Italy. Ind. Crops Prod. 2000, 11, 179-186.

23. Amaducci, S.; Monti, A.; Venturi, G. Non-structural carbohydrates and fibre components in sweet and fibre sorghum as affected by low and normal input techniques. Ind. Crops Prod. 2004, 20, 111-118.

24. Mahmood, A.; Honermeier, B. Chemical composition and methane yield of sorghum cultivars with contrasting row spacing. Field Crops Res. 2012, 128, 27-33.

25. Zegada-Lizarazu, W.; Monti, A. Energy crops in rotation: A review. Biomass Bioenergy 2011, 35, $12-25$.

26. Zegada-Lizarazu, W.; Monti, A. Are we ready to cultivate sweet sorghum as a bioenergy feedstock? A review on field management practices. Biomass Bioenergy 2012, 40, 1-12.

27. Barbanti, L.; Grandi, S.; Vecchi, A.; Venturi, G. Sweet and fibre sorghum (Sorghum bicolor (L.) moench), energy crops in the frame of environmental protection from excessive nitrogen loads. Eur. J. Agron. 2006, 25, 30-39.

28. Marelli, L.; Mulligan, D.; Edwards, R. Critical Issues in Estimating ILUC Emissions; EUR 24816 EN; European Commission-Joint Research Centre: Ispra, Italy, 2011.

29. Searchinger, T.; Heimlich, R.; Houghton, R.A.; Dong, F.; Elobeid, A.; Fabiosa, J.; Tokgoz, S.; Hayes, D.; Yu, T.H. Use of US croplands for biofuels increases greenhouse gases through emissions from land-use change. Science 2008, 319, 1238-1240.

30. Styles, D.; Gibbons, J.; Williams, A.P.; Stichnothe, H.; Chadwick, D.R.; Healey, J.R. Cattle feed or bioenergy? Consequential life cycle assessment of biogas feedstock options on dairy farms. GCB Bioenergy 2014, doi:10.1111/gcbb.12189.

31. General guide for life cycle assessment-Detailed guidance. In International Reference Life Cycle Data System (ILCD) Handbook, 1st ed.; European Commission-Joint Research Centre: Luxembourg, 2010.

32. Environmental Management-Life Cycle Assessment-Principles and Framework; EN ISO 14040:2006; International Organisation for Standardisation: Brussels, Belgium, 2006.

33. Environmental Management-Life Cycle Assessment-Requirements and Guidelines; EN ISO 14044:2006; International Organisation for Standardisation: Brussels, Belgium, 2006.

34. PE International AG. Available online: www.pe-international.com (accessed on 10 December 2014).

35. Plevin, R.J.; Delucchi, M.A.; Creutzig, F. Using attributional life cycle assessment to estimate climate-change mitigation benefits misleads policy makers. J. Ind. Ecol. 2014, 18, 73-83.

36. Recommendations for life cycle impact assessment in the European context. In International Reference Life Cycle Data System (ILCD) Handbook, 1st ed.; Hauschild, M., Goedkoop, M., Guinée, J.B., Heijungs, R., Huijbregts, M.A.J., Jolliet, O., Margni, M., de Schryver, A., Pennington, D., Pant, R., et al., Eds.; European Commission-Joint Research Centre: Luxembourg, 2011.

37. Agostini, A.; Giuntoli, J.; Boulamanti, A. Carbon Accounting of Forest Bioenergy. Conclusions and Recommendations from a Critical Literature Review; EUR 25354 EN; European Commission—Joint Research Centre: Ispra, Italy, 2014. 
38. Marañón, E.; Salter, A.M.; Castrillón, L.; Heaven, S.; Fernández-Nava, Y. Reducing the environmental impact of methane emissions from dairy farms by anaerobic digestion of cattle waste. Waste Manag. 2011, 31, 1745-1751.

39. Chantigny, M.H.; Angers, D.A.; Rochette, P.; Bélanger, G.; Massé, D.; Côté, D. Gaseous nitrogen emissions and forage nitrogen uptake on soils fertilized with raw and treated swine manure. J. Environ. Qual. 2007, 36, 1864-1872.

40. Loria, E.R.; Sawyer, J.E. Extractable soil phosphorus and inorganic nitrogen following application of raw and anaerobically digested swine manure. Agron. J. 2005, 97, 879-885.

41. Möller, K.; Stinner, W.; Deuker, A.; Leithold, G. Effects of different manuring systems with and without biogas digestion on nitrogen cycle and crop yield in mixed organic dairy farming systems. Nutr. Cycl. Agroecosystems 2008, 82, 209-232.

42. Ecoinvent Database v2.2; Swiss Centre for Life Cycle Inventories: Dübendorf, Switzerland, 2014

43. Fabbri, C.; Baldrighi, C. Più biogas integrando i reflui zootecnici con silomais. L'Inf. Agrar. 2012, 5, 30-33. (In Italian)

44. Fabbri, C.; Piccinini, S.; Verzellesi, F. Biogas da soli reflui zootecnici, buona la resa energetica. L'Inf. Agrar. 2011, 38, 20-24. (In Italian)

45. Fabbri, C.; Shams-Eddin, S.; Bondi, F.; Piccinini, S. Efficienza e problematiche di un impianto di digestione anaerobica a colture dedicate. Ing. Ambient. 2011, 40, 29-40.

46. Koehler, B.; Diepolder, M.; Ostertag, J.; Thurner, S.; Spiekers, H. Dry matter losses of grass, lucerne and maize silages in bunker silos. Agric. Food Sci. 2013, 22, 145-150.

47. Herrmann, C.; Heiermann, M.; Idler, C. Effects of ensiling, silage additives and storage period on methane formation of biogas crops. Bioresour. Technol. 2011, 102, 5153-5161.

48. Schittenhelm, S. Effect of drought stress on yield and quality of maize/sunflower and maize/sorghum intercrops for biogas production. J. Agron. Crop Sci. 2010, 196, 253-261.

49. MAN Truck \& Bus; Gas Engines for CHP Units and Gensets. Available online: http://www.truck.man.eu/man/media/content_medien/doc/global_engines/power/BR_Power_Gas_ EN.pdf?_ga=1.109727301.1989443271.1432903866 (accessed on 10 December 2014).

50. Walla, C.; Schneeberger, W. The optimal size for biogas plants. Biomass Bioenergy 2008, 32, 551-557.

51. Kristensen, P.G.; Jensen, J.K.; Nielsen, M.; Illerup, J.B. Emission Factors for Gas Fired chp Units $<25$ Mw; Danish Gas Technology Centre, Hørsholm, Denmark, 2004.

52. Liebetrau, J.; Clemens, J.; Cuhls, C.; Hafermann, C.; Friehe, J.; Weiland, P.; Daniel-Gromke, J. Methane emissions from biogas-producing facilities within the agricultural sector. Eng. Life Sci. 2010, 10, 595-599.

53. Li, Z.; Yin, F.; Li, H.; Wang, X.; Lian, J. A novel test method for evaluating the methane gas permeability of biogas storage membrane. Renew. Energy 2013, 60, 572-577.

54. Agriculture, forestry and other land use. In 2006 IPCC Guidelines for National Greenhouse Gas Inventories; Egglestone, S., Buendia, L., Miwa, K., Ngara, T., Tanabe, K., Eds.; IPCC: Hayama, Japan, 2006; Volume 4.

55. Amon, B.; Kryvoruchko, V.; Amon, T.; Zechmeister-Boltenstern, S. Methane, nitrous oxide and ammonia emissions during storage and after application of dairy cattle slurry and influence of slurry treatment. Agric. Ecosyst. Environ. 2006, 112, 153-162. 
56. Amon, B.; Kryvoruchko, V.; Moitzi, G.; Amon, T. Greenhouse gas and ammonia emission abatement by slurry treatment. Int. Congr. Ser. 2006, 1293, 295-298.

57. Weiland, P.; Gemmeke, B.; Rieger, C. Biogas-Messprogramm II-61 Biogasanlagen im Vergleich; Fachagentur Nachwachsende Rohstoffe e.V. FNR: Gülzow-Prüzen, Germany, 2009. (In German)

58. Muñoz, I.; Schmidt, J.H.; Brandão, M.; Weidema, B.P. Rebuttal to 'indirect land use change (ILUC) within life cycle assessment (LCA) - Scientific robustness and consistency with international standards'. GCB Bioenergy 2014, doi:10.1111/gcbb.12231.

59. Carrosio, G. Energy production from biogas in the italian countryside: Policies and organizational models. Energy Policy 2013, 63, 3-9.

60. Posch, M.; Seppälä, J.; Hettelingh, J.P.; Johansson, M.; Margni, M.; Jolliet, O. The role of atmospheric dispersion models and ecosystem sensitivity in the determination of characterisation factors for acidifying and eutrophying emissions in lcia. Int. J. Life Cycle Assess. 2008, 13, 477-486.

61. Seppälä, J.; Posch, M.; Johansson, M.; Hettelingh, J.P. Country-dependent characterisation factors for acidification and terrestrial eutrophication based on accumulated exceedance as an impact category indicator. Int. J. Life Cycle Assess. 2006, 11, 403-416.

62. Rabl, A.; Spadaro, J.V. The Riskpoll Software. Available online: http://www.arirabl.com/software (accessed on 10 December 2014).

63. Greco, S.L.; Wilson, A.M.; Spengler, J.D.; Levy, J.I. Spatial patterns of mobile source particulate matter emissions-to-exposure relationships across the united states. Atmos. Environ. 2007, 41, 1011-1025.

64. Goedkoop, M.; Heijungs, R.; Huijbregts, M.A.J.; de Schryver, A.; Struijs, J.; van Zelm, R. A Life Cycle Impact Assessment Method which Comprises Harmonised Category Indicators at the Midpoint and the Endpoint Level; RIVM (Dutch National Institute for Public Health and the Environment): Bilthoven, The Netherlands, 2012.

65. Abdalla, M.; Osborne, B.; Lanigan, G.; Forristal, D.; Williams, M.; Smith, P.; Jones, M. Conservation tillage systems: A review of its consequences for greenhouse gas emissions. Soil Use Manag. 2013, 29, 199-209.

66. Snyder, C.; Bruulsema, T.; Jensen, T.; Fixen, P. Review of greenhouse gas emissions from crop production systems and fertilizer management effects. Agric. Ecosyst. Environ. 2009, 133, 247-266.

67. Zhang, S.; Li, Q.; Lü, Y.; Zhang, X.; Liang, W. Contributions of soil biota to c sequestration varied with aggregate fractions under different tillage systems. Soil Biol. Biochem. 2013, 62, 147-156.

68. Derpsch, R.; Franzluebbers, A.J.; Duiker, S.W.; Reicosky, D.C.; Koeller, K.; Friedrich, T.; Sturny, W.G.; Sá, J.C.M.; Weiss, K. Why do we need to standardize no-tillage research? Soil Tillage Res. 2014, 137, 16-22.

69. Franzluebbers, A.J. Achieving soil organic carbon sequestration with conservation agricultural systems in the Southeastern United States. Soil Sci. Soc. Am. J. 2010, 74, 347-357.

70. Soane, B.D.; Ball, B.C.; Arvidsson, J.; Basch, G.; Moreno, F.; Roger-Estrade, J. No-till in northern, western and south-western Europe: A review of problems and opportunities for crop production and the environment. Soil Tillage Res. 2012, 118, 66-87.

71. Directive of the Council of 12 December 1991 Concerning the Protection of Waters against the Pollution Caused by Nitrates from Agricultural Sources; 91/676/EEC; European Union: Luxembourg, 1991 
72. Mircea, M.; Ciancarella, L.; Briganti, G.; Calori, G.; Cappelletti, A.; Cionni, I.; Costa, M.; Cremona, G.; D'Isidoro, M.; Finardi, S. Assessment of the AMS-MINNI system capabilities to simulate air quality over italy for the calendar year 2005. Atmos. Environ. 2014, 84, 178-188.

73. Tabaglio, V.; Gavazzi, C. Yield performance of maize (Zea mays 1.) cropped under conventional tillage and no-tillage in Northern Italy. Agric. Mediterr. 2006, 136, 198-205.

74. Tabaglio, V.; Gavazzi, C. Monoculture maize (Zea mays 1.) cropped under conventional tillage, no-tillage and n fertilization: (I) Three year yield performances. Italian J. Agron. 2009, 4, 61-68.

75. Pirlo, G.; Carè, S. A simplified tool for estimating carbon footprint of dairy cattle milk. Italian J. Anim. Sci. 2013, 12, doi:10.4081/ijas.2013.e81.

76. Sanz-Cobena, A.; Sánchez-Martín, L.; García-Torres, L.; Vallejo, A. Gaseous emissions of $\mathrm{N}_{2} \mathrm{O}$ and $\mathrm{NO}$ and $\mathrm{NO}^{3-}$ leaching from urea applied with urease and nitrification inhibitors to a maize (Zea mays) crop. Agric. Ecosyst. Environ. 2012, 149, 64-73.

77. Hutchings, N.; Webb, J.; Amon, B. Crop production and agricultural soils. In EMEP/EEA Emission Inventory Guidebook 2009; European Environment Agency: Copenhagen, Denmark, 2009.

78. Stehfest, E.; Bouwman, L. $\mathrm{N}_{2} \mathrm{O}$ and $\mathrm{NO}$ emission from agricultural fields and soils under natural vegetation: Summarizing available measurement data and modeling of global annual emissions. Nutr. Cycl. Agroecosyst. 2006, 74, 207-228.

79. Perego, A.; Basile, A.; Bonfante, A.; De Mascellis, R.; Terribile, F.; Brenna, S.; Acutis, M. Nitrate leaching under maize cropping systems in Po Valley (Italy). Agric., Ecosyst. Environ. 2012, 147, 57-65.

80. Rossier, D.; Raphael, C. Ecobilan: Adaptation de la Méthode Écobilan pour la Gestion Environnementale de L'exploitation Agricole; Graduate Institute of International and Development Studies: Lausanne, Switzerlqnd, 1998.

81. Van der Werf, H.M.G.; Kanyarushoki, C.; Corson, M.S. An operational method for the evaluation of resource use and environmental impacts of dairy farms by life cycle assessment. J. Environ. Manage. 2009, 90, 3643-3652.

82. Winther, M.; Nielsen, O.-K. Fuel Use and Emissions from Non-Road Machinery in Denmark from 1985-2004 and Projections from 2005-2030; Miljoestyrelsen: Copenhagen, Denmark, 2006.

83. Álvaro-Fuentes, J.; Plaza-Bonilla, D.; Arrúe, J.; Lampurlanés, J.; Cantero-Martínez, C. Soil organic carbon storage in a no-tillage chronosequence under Mediterranean conditions. Plant Soil 2014, 376, 31-41.

84. Baker, J.M.; Ochsner, T.E.; Venterea, R.T.; Griffis, T.J. Tillage and soil carbon sequestrationWhat do we really know? Agric. Ecosyst. Environ. 2007, 118, 1-5.

85. Borin, M.; Menini, C.; Sartori, L. Effects of tillage systems on energy and carbon balance in north-eastern Italy. Soil Tillage Res. 1997, 40, 209-226.

86. De Sanctis, G.; Roggero, P.P.; Seddaiu, G.; Orsini, R.; Porter, C.H.; Jones, J.W. Long-term no tillage increased soil organic carbon content of rain-fed cereal systems in a Mediterranean area. Eur. J. Agron. 2012, 40, 18-27.

87. Powlson, D.S.; Stirling, C.M.; Jat, M.; Gerard, B.G.; Palm, C.A.; Sanchez, P.A.; Cassman, K.G. Limited potential of no-till agriculture for climate change mitigation. Nat. Clim. Change 2014, 4, 678-683. 
88. Edwards, R.; Mulligan, D.; Marelli, L. Indirect Land Use Change from Increased Biofuels Demand. Comparison of Models and Results for Marginal Biofuels Production from Different Feedstocks; EUR 24485 EN; European Commission-Joint Research Centre: Ispra, Italy, 2010.

89. Proposal for a Directive of the European Parliament and of the Council Amending Directive 98/70/ec Relating to the Quality of Petrol and Diesel Fuels and Amending Directive 2009/28/ec on the Promotion of the Use of Energy from Renewable Sources. European Commission: Brussels, Belgium, 2012.

90. Laborde, D. Assessing the Land Use Change Consequences of European Biofuel Policies; International Food Policy Institute (IFPRI): Washington, USA, 2011.

91. Laborde, D.; Padella, M.; Edwards, R.; Marelli, L. Progress in Estimates of ILUC with Mirage Model; EUR 26106 EN; European Commission-Joint Research Centre: Ispra, Italy, 2014.

92. Edwards, R.; Larivé, J.-F.; Rickeard, R.; Weindorf, W. JEC Well-to-Wheels Analysis of Future Automotive Fuels and Powertrains in the European Context-Well-to-tank (WTT); Report v.4.A EUR 26237 EN; European Commission-Joint Research Centre: Ispra, Italy, 2014.

(C) 2015 by the authors; licensee MDPI, Basel, Switzerland. This article is an open access article distributed under the terms and conditions of the Creative Commons Attribution license (http://creativecommons.org/licenses/by/4.0/). 